\title{
Early medieval Italian Alps: reconstructing diet and mobility in the valleys
}

\author{
Alice Paladin ${ }^{1,2}$ (1) - Negahnaz Moghaddam ${ }^{3,4} \cdot$ Agnieszka Elzbieta Stawinoga $^{5} \cdot$ Inga Siebke $^{3}$. \\ Valentina Depellegrin ${ }^{6}$. Umberto Tecchiati ${ }^{7}$. Sandra Lösch $^{3}$ (I) $\cdot$ Albert Zink $^{1}$
}

Received: 21 August 2018 / Accepted: 29 October 2019 / Published online: 4 March 2020

(C) The Author(s) 2020

\begin{abstract}
In Early Middle Ages (sixth-eleventh centuries AD), South Tyrol (Italian Alps) played a key role for geographical and military reasons. Historical sources document that allochthonous groups (germani) entered the territory, and the material culture shows mutual cultural exchanges between autochthonous and germani. Besides the nature of the migration, the demographic and socio-cultural impacts on the local population are still unknown. Stable isotope analyses were performed to provide insights into dietary patterns, subsistence strategies, changes in socio-economic structures, and mobility, according to spatial (e.g. valleys, altitudes) and chronological (centuries) parameters. Bone collagen of 32 faunal and 91 human bone samples from nine sites, located at different altitudes, was extracted for stable carbon, nitrogen, and sulphur isotope analyses. In total, 94\% (30/32) of the faunal remains were of good quality, while the humans displayed $93 \%$ (85/91) of good quality samples for $\delta^{13} \mathrm{C}$ and $\delta^{15} \mathrm{~N}$ and $44 \%(40 / 91)$ for $\delta^{34} \mathrm{~S}$ stable isotopes. The isotopic results of the animals reflected a terrestrial-based diet. Statistical differences were observed within and among the humans of the different valleys. The $\delta^{13} \mathrm{C}$ values of individuals sampled from higher altitudes indicated a mainly $\mathrm{C}_{3}$ plant-based diet compared to areas at lower altitudes, where more positive $\delta^{13} \mathrm{C}$ values showed an intake of $\mathrm{C}_{4}$ plants. The $\delta^{15} \mathrm{~N}$ values suggested a terrestrial-based diet with a greater consumption of animal proteins at higher altitudes. The data revealed higher variability in $\delta^{34} \mathrm{~S}$ values in the Adige valley, with individuals probably migrating and/or changing dietary habits.
\end{abstract}

Keywords Stable isotopes $\cdot$ Migration $\cdot$ Diet $\cdot$ Early middle ages $\cdot$ Italian Alps

Sandra Lösch and Albert Zink should be considered as joint senior authors.

Electronic supplementary material The online version of this article (https://doi.org/10.1007/s12520-019-00982-6) contains supplementary material, which is available to authorized users.

Alice Paladin

alice.paladin@eurac.edu

1 Institute for Mummy Studies, Eurac Research, Viale Druso 1, 39100 Bolzano, Italy

2 Institute for Archaeological Sciences, WG: Paleoanthropology, University of Tübingen, 72070 Tubingen, Germany

3 Department of Physical Anthropology, Institute of Forensic Medicine, University of Bern, Sulgenauweg 40,

3007 Bern, Switzerland
4 Unit of Forensic Imaging and Anthropology, University Center of Legal Medicine Lausanne-Geneva, Chemin de la Vulliette 4, CH-1000, 25 Lausanne, Switzerland

5 Management and Committees, Eurac Research, Viale Druso 1, 39100 Bolzano, Italy

6 Institut für Vor-und Frühgeschichtliche Archäologie \& ArchaeoBioCenter, Ludwig-Maximilians-Universität, Geschwister-Scholl-Platz 1, 80539 Munich, Germany

7 Dipartimento di Beni Culturali e Ambientali, PrEcLab - Laboratorio di Preistoria, Protostoria ed Ecologia Preistorica, Università degli studi di Milano, Via Festa del Perdono 7, 20122 Milan, Italy 


\section{Introduction}

\section{Early medieval South Tyrol: historical and archaeological context}

South Tyrol (Trentino-Alto Adige) is an Alpine region in northern Italy. After the fall of the Western Roman Empire, South Tyrol was the scene of power struggles and dynastic disputes due to the change of military forces, such as the Byzantines (Eastern Roman Empire) and the germani or barbari (e.g. Goths, Franks, Bavarians, Langobards). The written records of such events are limited and mainly derive from the account of Paul the Deacon, Historia Langobardorum (eighth century AD) and a few other historical documents (Cavada 2004). The archaeological findings document a prolonged usage of the Roman defensive constructions, at least until the late fifth century $\mathrm{AD}$ (Heitmeier 2005; Marzoli et al. 2009). Starting from the sixth century $\mathrm{AD}$, the Alemannic and Frank military elites entered the region from the northwest (Venosta valley). The Langobards first crossed Noricum from the east and then into the territory of Bolzano in $568 \mathrm{AD}$ (Kustatscher and Romeo 2010). Moreover, Bavarians came from the northeast (Inntal and Alta Isarco valley), whereas the Slavic groups entered South Tyrol from the eastern Pusteria valley (Giostra and Lusuardi Siena 2004; Haas-Gebhard 2004). In this scenario, alliances for the domain of the territory between high status families subjected the valleys to continuously changing borders and presumably led to the migration of people. Toponymy and archaeological discoveries do not allow for any conclusions to be drawn regarding the possible settlement of the germani groups (Bierbrauer 1991; Marzoli et al. 2009). Additionally, the Early medieval burial sites in South Tyrol have been only partially investigated (Albertoni 2005) and, until recently, a limited number of individuals have been studied anthropologically. This leads to gaps in our knowledge about the past populations in this territory. The material culture from the funerary contexts exemplifies a mutual mixing of cultural habits due to a slow but broad hybridity between autochthonous and allochthonous practices (Albertoni 2005; Gasparri and La Rocca 2013). However, it remains unclear whether these changes were limited to the introduction of foreign cultural goods or accompanied by an admixture of newly arrived groups with the local population (Dal Ri and Rizzi 1995).

For the Middle Ages, the paleoclimatic data document a climatic pessimum during the sixth-eighth centuries $\mathrm{AD}$, which was marked by cold, humid weather with increased precipitation and lower temperatures (Ortolani and Pagliuca 2007). Some warmer periods are supported by pollen analyses from the Swiss Alps during the fourth-fifth century AD and the eightheleventh century AD (Tinner et al. 2003). The later medieval Warm Period corresponded to the prolonged climatic optimum phase (approx. 950-1250 AD), which was characterised by warm hemispheric conditions (Hughes and Diaz 1994; Mann et al. 2009), that could have intensified the cultivation of $\mathrm{C}_{4}$ plant, such as different millet species, which fix carbon more efficiently at higher temperature (Ehleringer et al. 1991, 2002). Isotopic studies regarding northern Italy Bronze Age bones showed that $\mathrm{C}_{4}$ plants, such as broomcorn millet (Panicum miliaceum) and/or foxtail millet (Setaria italica) already provided an important dietary contribution for both humans and animals (Tafuri et al. 2009, 2018; Varalli et al. 2016). Additionally, a paleodietary study on Celtic population (approx. 2100 years BP) from northeast Italy documented a predominant consumption of cultivated $\mathrm{C}_{4}$ plants (Laffranchi et al. 2016).

In the present study, isotopic analyses were conducted to gain information on dietary and mobility patterns of Early medieval populations in the Italian Alps for the first time. Carbon $\left({ }^{13} \mathrm{C} /{ }^{12} \mathrm{C}\right)$, nitrogen $\left({ }^{15} \mathrm{~N} /{ }^{14} \mathrm{~N}\right)$, and sulphur $\left({ }^{34} \mathrm{~S} /{ }^{32} \mathrm{~S}\right)$ isotope ratios of human and animal bone collagen were analysed from skeletal remains found at nine archaeological sites located in the alpine areas. Considering the significant distance of the studied territory from the coastal zones, the sea spray effect is not supposed to influence the data. The objectives of this project are to (i) gain insight into the inter- and intra-isotopic variability throughout both areas (sites, valleys, altitudes) and time to understand the human subsistence strategies, changes in socio-economic structures and possible adaptation to the environment and (ii) provide information about mobility, according to spatial (valleys) and chronological (centuries) parameters.

\section{Stable isotope measurements: reconstructing diet and mobility}

Stable isotope analysis is an established scientific method in bioarchaeology for the evaluation of dietary and migration patterns of past populations (e.g. Ambrose 1993; Fuller et al. 2012; Lösch et al. 2006, 2014). Today, isotopic studies on Early medieval skeletal remains are of growing interest (e.g. Hakenbeck et al. 2010, 2017; Hemer et al. 2013; Knipper et al. 2012; Lösch 2009; McGlynn 2007; Iacumin et al. 2014; Reitsema and Vercellotti 2012). With the Copper Age Iceman being an exception (Hoogewerff and Papesch 2001; Macko et al. 1999), in South Tyrol, there is a lack of comparative framework, and almost no isotope analyses on human bones have been performed.

Stable carbon $\left({ }^{13} \mathrm{C} /{ }^{12} \mathrm{C}\right)$ and nitrogen $\left({ }^{15} \mathrm{~N} /{ }^{14} \mathrm{~N}\right)$ isotope ratios are usually examined to study the diet of past humans and/or animals (e.g. Craig et al. 2009; Halffman and Velemínský 2015). In particular, the analysis of $\delta^{13} \mathrm{C}$ values is necessary for the distinction between $\mathrm{C}_{3}$ or $\mathrm{C}_{4}$ plant sources, as $\mathrm{C}_{3}$ plants (e.g. wheat and barley) provide more negative $\delta^{13} \mathrm{C}$ values (approx. 35 to $-19 \%$ ) than $\mathrm{C}_{4}$ plants (approx. -15 to $-9 \%$ ) (Lee-Thorp 2008; Meier-Augenstein 2010). The analysis of $\delta^{15} \mathrm{~N}$ values refers to animal protein consumption, both marine and/or terrestrial sources (Richards et al. 1998). An increase of $\delta^{15} \mathrm{~N}$ values 
provides information on the trophic level, as prey-predator collagen enrichment accounts for $\delta^{15} \mathrm{~N}$ values of +3 to $+5 \%$ o (Ambrose 1993; Hedges and Reynard 2007; Lee-Thorp et al. 1989). The trophic level enrichment for $\delta^{13} \mathrm{C}$ is less increased with approximately + 1\%o (DeNiro and Epstein 1978; Minagawa and Wada 1984). Analyses from faunal bones are fundamental to reconstruct the faunal-human trophic relationship (Van Klinken et al. 2000). This serves as a reference for the general status of a population and for the reconstruction of the dietary sources in an archaeological context. Furthermore, this study presents sulphur $\left(\delta^{34} \mathrm{~S}\right)$ isotope data for the reconstruction of the human diet (e.g. freshwater sources), and particularly for its application on mobility. The values of $\delta^{34} \mathrm{~S}$ are of growing interest in numerous archaeological studies (e.g. Bollongino et al. 2013; Craig et al. 2006; Lösch et al. 2014; Moghaddam et al. 2016, 2018; Nehlich et al. 2011, 2012, 2014; Oelze et al. 2012; Privat et al. 2007; Richards et al. 2001, 2003; Tafuri et al. 2018; Varalli et al. 2016; Vika 2009). Regarding the oceanic effects, the local geological context and the atmospheric precipitations are mainly influencing the $\delta^{34} \mathrm{~S}$ values. Hence, the isotopic signature in human and animal bones reflects the diet as well as the habitat (Nehlich et al. 2011; Vika 2009). Little is known about the $\delta^{34} \mathrm{~S}$ trophic level shift; however, studies showed that a slight increase of $+0.5 \% \circ \pm 2.4 \%$ is observed between consumers and their diet (Nehlich 2015). In terrestrial environments, rivers generally exhibit $\delta^{34} \mathrm{~S}$ values between -5 and $+15 \%$; however, they are dependent on the local geology. Therefore, the values can vary greatly (Nehlich 2015). Thus, individuals living in terrestrial riverine landscapes would be expected to show $\delta^{34} \mathrm{~S}$ values within the stated range, or slightly above, due to a trophic shift in general.

\section{Materials and methods}

The study was performed on human and faunal skeletal remains from nine archaeological sites (Fig. 1a), located in three valleys and one basin in South Tyrol (Italy), which are crossed by two main rivers, the Adige in the west, and the Isarco in the northeast. The sites have been excavated over the last 30 years and are located in various ecological environments of those valleys (e.g. valley floor, hill and mountain) (Table S1). All sites are from a small territory with different levels of precipitations and temperatures (Winckler 2012), especially with regard to the altitude differences (Fig. 1b). In the Adige valley, sites are located at the lowest altitudes (mean $348 \mathrm{~m}$ a.s.1.), while the highest are in the Venosta valley (mean $1279 \mathrm{~m}$ a.s.1.). The site in Merano basin is at $641 \mathrm{~m}$ a.s.1. and the Isarco valley site is at $817 \mathrm{~m}$ a.s.l. (Fig. 1b).

About 121 Early medieval tombs (Adige valley: 21 tombs; Merano basin: 31; Isarco valley: 49 and Venosta valley: 20) were recovered. Nevertheless, some of the human remains came from archaeological stratigraphic units without a clear tomb structure. At the burial sites of Castel Tirolo (Merano basin) and Malles Burgusio St. Stefano (Verosta valley), the tombs were found inside and/or around a church or, as in Terlano, surrounding a Paleochristian baptistery. The latter site was located next to areas of worships, maybe due to the presence of sulphurous water springs (Lunz 1974; Tecchiati and Zanforlin 2010). When available, the archaeological data on grave goods were obtained from the original archaeological survey documentation (unpublished data) or from published sources (e.g. Marzoli et al. 2009; Marzoli 2002; Reuß 2016) (Table S1). The greatest quantity of grave goods was found in Bressanone Elvas: knives, scramasax (weapon), parts of belts, necklaces with amber and/or glass beads, earrings and bracelets dating (relative dating) approximately to the seventh century AD (Kaufmann and Demetz 2004: 76).

In this study, 91 human (Table S1) and 32 faunal remains (Table S2) were obtained for the isotopic analyses. The faunal bone samples, 11 (34\%) from Adige, 7 (22\%) from Merano basin, 3 (9\%) from Isarco and 11 (34\%) from Venosta, were contemporary to the human samples. Out of the 91 humans, $23(25 \%)$ samples were selected from skeletons found in Adige valley, 24 (26\%) from Merano basin, 21 (23\%) from Isarco valley and 23 (25\%) from Venosta valley.

\section{Osteological analyses}

Age at death and sex were estimated using established anthropological methods. For the age at death of adults, the pubic symphysis, the epiphyseal-diaphyseal fusions and the ectocranial suture closures were evaluated (Acsádi and Nemeskéri 1970; Meindl and Lovejoy 1985; Schaefer et al 2009; Brooks and Suchey 1990). The age at death for subadults was based on the eruption of the deciduous and permanent dentition (AlQathani et al. 2010; Ubelaker 1978), the measure of diaphyseal lengths, and the assessment of the epiphyseal-diaphyseal fusions (Fazekas and Kósa 1978; Maresh 1970; Schaefer et al 2009). Individuals were attributed to the following age groups: perinatal (3840 weeks); newborn ( $0-2$ months); infant 1 st ( 3 months6 years); infant 2 nd ( $7-12$ years); juvenile (13-19 years); adult (20-40 years); adult not determinable (n.d.; > 20 years); mature (40-59 years); and senile ( $>60$ years). The sex of adult individuals ( $>20$ years) was estimated based on sexual dimorphism of various skeletal elements as described by Buikstra and Ubelaker (1994); Ferembach et al. (1979) and Murail et al. (2005). In subadults ( $<20$ years), the sex was not determined due to the ambiguity of specific sexual traits (Baker et al. 2005).

\section{Archaeozoological analyses}

In South Tyrol, a limited number of archaeozoological studies on Early medieval faunal remains have been conducted (e.g. 
Fig. 1 a Map of South Tyrol, Italy, displaying the locations of the archaeological sites and valleys. Adige valley (Etschtal): (1) Appiano, S. Paolo

Castelvecchio (Eppan, St. Paul Altenburg), (2) Montagna, Pinzano (Montan, Pinzon), (3) Nalles (Nals), (4) Terlano (Terlan); Merano basin (Meraner Becken): (5) Castel Tirolo (Schloss Tirol); Isarco valley (Eisacktal): (6) Bressanone Elvas necropoli 17 (Brixen, Elvas); Venosta valley (Vinschgau): (7) Tanas (St. Peter's path), (8) Malles, Burgusio S. Stefano (Mals, Burgeis St. Stephan), (9) Malles, Maso Pauli (Mals, Paulihof). $\mathbf{b}$ The altitudes of the nine sites are indicated in meters above sea level (m a.s.l.)

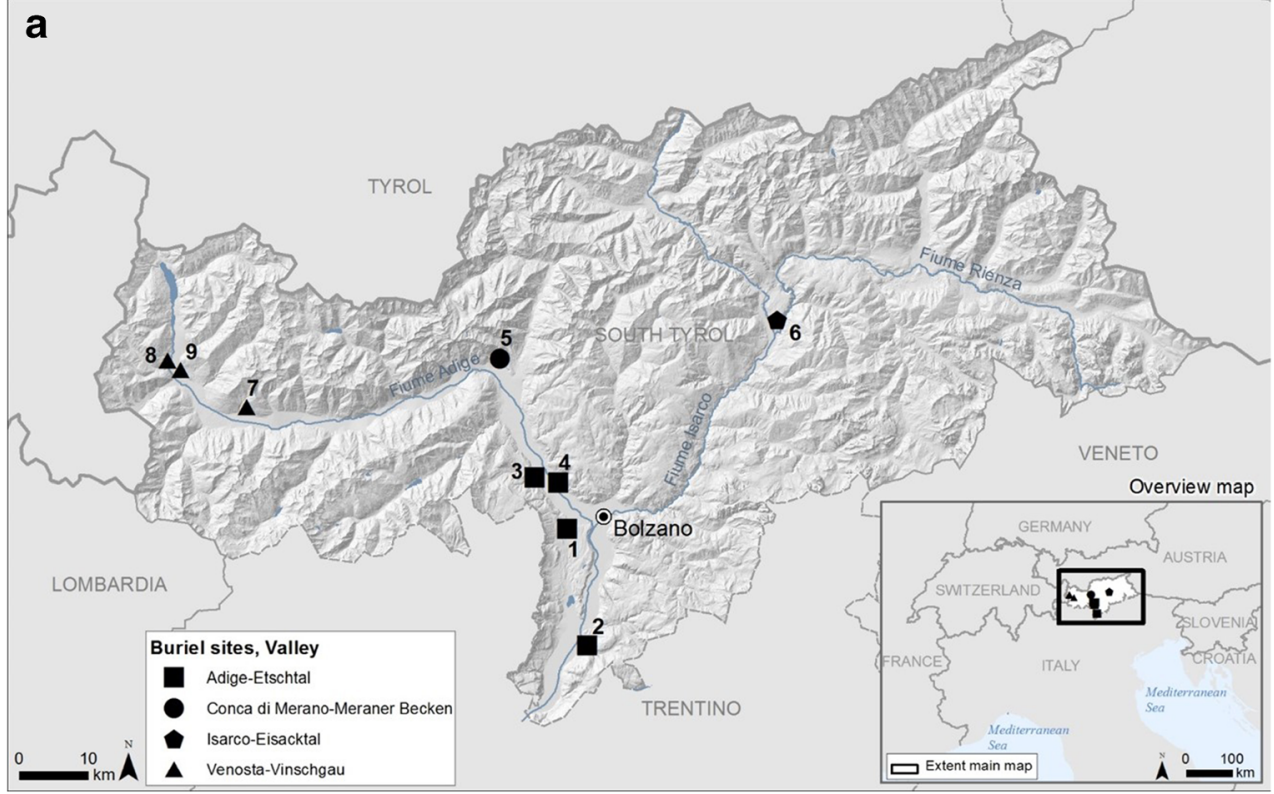

b

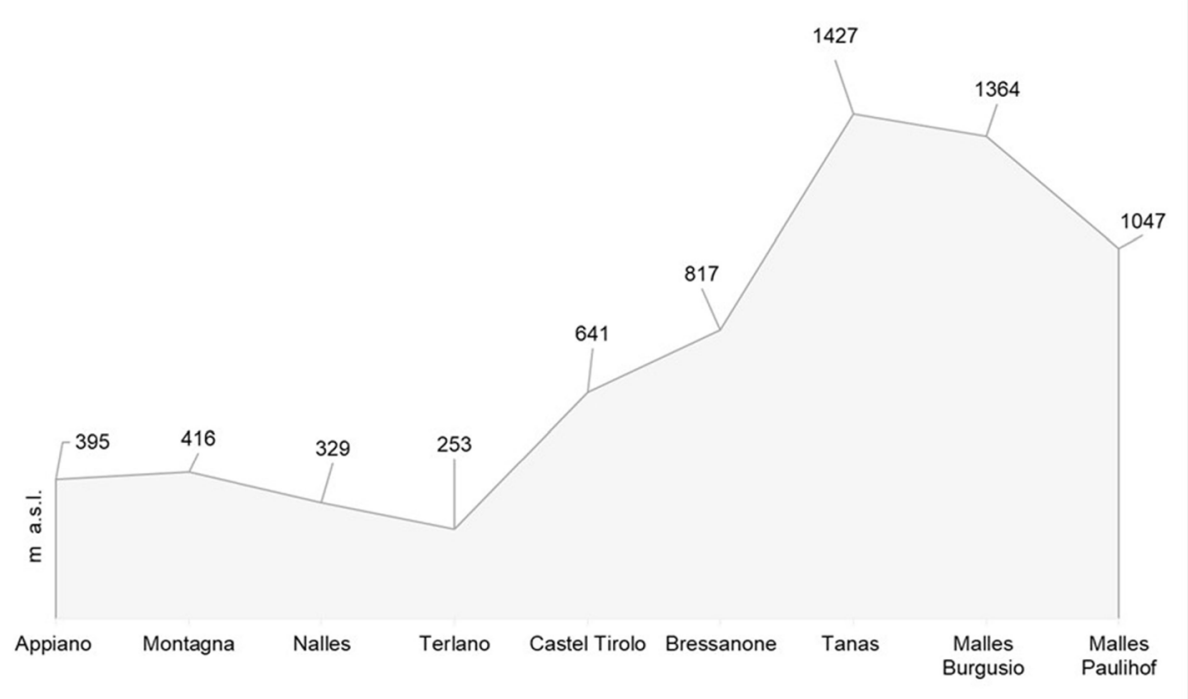

Riedel 1979; Dallago 2016; Sardagna and Tecchiati 2010). Faunal bone materials $(n=32)$, from the same sites and possibly from the same stratigraphic units as the human remains, were sampled. The determination of the taxonomy and the anatomical identification of the faunal remains were undertaken, referring to Schmid (1972) and Barone (1980), as well as to the osteological collection of the laboratory for Archaeozoology of the Archaeological Heritages Office of the Autonomous Province of Bolzano-Bozen.

\section{Stable isotope analyses: analytical method and quality criteria}

For $\delta^{13} \mathrm{C}, \delta^{15} \mathrm{~N}$ and $\delta^{34} \mathrm{~S}$ analyses, human bone samples were collected from cranial bones; if these were unavailable, the diaphysis of long bones were used (Table S1). The extraction of bone collagen was performed following an acid-base extraction modified after Longin (1971) and Ambrose (1990). After cleaning with distilled water, all samples were pulverized. Then, $500 \mathrm{mg}$ of bone powder was demineralized with $10 \mathrm{ml}$ of $1 \mathrm{M}$ hydrochloric acid ( $\mathrm{HCl}$ ) for $20 \mathrm{~min}$. The solution was then neutralized $(\mathrm{pH} \sim 6-7)$ and treated with $10 \mathrm{ml}$ of $0.125 \mathrm{M}$ of sodium hydroxide $(\mathrm{NaOH})$ for $20 \mathrm{~h}$ to remove humic acids. After a neutralization phase, $10 \mathrm{ml}$ of $0.001 \mathrm{M}$ $\mathrm{HCl}$ (ideally $\mathrm{pH} 3$ ) was added and placed in a water bath for incubation at $90{ }^{\circ} \mathrm{C}(10-17 \mathrm{~h})$. The solubilized collagen was filtered (VitraPOR filter-funnel, porosity 16-40 $\mu \mathrm{m}$ ) and lyophilized ( $0.42 \mathrm{mbar})$ for a minimum of $48 \mathrm{~h}$. From each sample, $3.0 \mathrm{mg} \pm 0.3 \mathrm{mg}$ collagen was weighted into tin capsules three times per specimen. The measurements of carbon 
$\left({ }^{13} \mathrm{C} /{ }^{12} \mathrm{C}\right)$, nitrogen $\left({ }^{15} \mathrm{~N} /{ }^{14} \mathrm{~N}\right)$ and sulphur $\left({ }^{34} \mathrm{~S} /{ }^{32} \mathrm{~S}\right)$ were performed by isotope ratio mass spectrometry (IRMS) at the Isolab GmbH of Schweitenkirchen, Germany. The average of the three measurements was calculated and used for the subsequent analyses. Results were reported in $\delta$-notation in units of per mil (\%o), according to the international standards: Vienna Pee Dee Belemnite (VPDB) for carbon, Ambient Inhalable Reservoir (AIR) for nitrogen and Vienna Canyon Diablo Troilite (V-CDT) for sulphur (Fry 2006; Hoefs 2009; Schoeniger and DeNiro 1984) and a laboratory internal collagen standard STD R (collagen from cowhide) from the EU project TRACE, such as $\delta^{13} \mathrm{C}$ vs V-PDB [\%o] $=-18.00 \pm$ $0.12 ; \delta^{15} \mathrm{~N}$ vs. AIR $[\% o]=+5.97 \pm 0.09 ; \delta^{34} \mathrm{~S}$ vs. V-CDT $[\% o]=+5.45 \pm 0.37(N=46$; one value consists of 3 to 4 averaged measurements). The analytical errors were recorded as less than $\pm 0.1 \%$ o for $\delta^{13} \mathrm{C}, \pm 0.2 \%$ or for $\delta^{15} \mathrm{~N}$ and $\pm 0.3 \%$ or $\delta^{34} \mathrm{~S}$. Samples with a value of $>1 \%$ collagen portion of dry bone were selected. In addition, samples were selected for statistical evaluation when the C:N $([\% \mathrm{C} / \% \mathrm{~N}] \times[14.007 /$ 12.011]) ratio were between 2.9-3.6 (DeNiro 1985), the C:S $([\% \mathrm{C} / \% \mathrm{~S}] \times[32.064 / 12.011])$ ratio between 300 and 900 , and the $\mathrm{N}: \mathrm{S}([\% \mathrm{~N} / \% \mathrm{~S}] \times[32.064 / 14.007])$ ratio between 100 and 300 (Nehlich and Richards 2009).

Good quality was also considered, when $\% \mathrm{C}$ was in the range of 30 to $47 \%$ and $\% \mathrm{~N}$ in the range of 11 to $17.3 \%$ (Ambrose 1990, 1993; Van Klinken 1999). When one specimen was slightly out of the range, but wt $\%$ collagen, the $\mathrm{C}: \mathrm{N}$ range, and either $\% \mathrm{C}$ or $\% \mathrm{~N}$ was within the stated criteria, the sample was still considered for statistical analyses. For sulphur, the $\% \mathrm{~S}$ values were taken when within the range of 0.15 to $0.35 \%$ (Nehlich and Richards 2009). Additionally, sulphur values were considered when the quality criteria for $\delta^{13} \mathrm{C}$ and $\delta^{15} \mathrm{~N}$ values were acceptable and $\% \mathrm{~S}$ values of all samples followed a similar trend. The outliers were discharged due to the limited sources of verified sulphur values.

\section{Statistical tests}

The faunal data was grouped depending on valleys and sites, on species, and on dietary habits (Table 1). The human data was organized according to the geographical locations (sites and valleys), sex and age at death and to the presence or absence of grave goods in the graves (Tables 1 and 2). Since most of the grave goods were recovered in the Isarco valley at Bressanone Elvas, statistical analyses were additionally conducted on this site. Moreover, the individuals were grouped in the following chronological intervals: phase 1: fifth-seventh centuries $\mathrm{AD}$, phase 2 : seventh-eighth centuries $\mathrm{AD}$, phase 3 : eighth-tenth centuries $A D$, phase 4: ninth-twelfth centuries $\mathrm{AD}$ and the individuals not ascribable to a specific phase were clustered into "Early Middle Ages" (sixth-eleventh centuries $\mathrm{AD}$ ) group (Tables 1 and 2).
The data was recorded in an Excel spreadsheet (Microsoft, Redmond, WA), and statistical analysis was performed using IBM $®$ SPSS $®$ Statistics 23 for Windows. After the analysis of distributions, the outliers in every valley (Tables S1 and S2) were excluded. Given the normality of the distributions (Shapiro-Wilk test), in order to compare the means of different groups, parametric statistical tests were applied. In the case of two groups, an independent-samples $t$ test was performed; otherwise, for more than two groups, the one-way ANOVA with post-hoc tests were applied.

For all tests, the significance level was set at 0.05 , and a $p$ value below 0.05 was considered significant.

\section{Results}

\section{Archaeozoological and osteological analyses}

The archaeozoological investigation resulted in 32 faunal remains. Bone samples were collected from 21 terrestrial herbivores (eight cattle Bos taurus, seven goats and/or sheep Capra hircus/Ovis aries, three deer Cervus elaphus and three horses Equus caballus; 66\%), two (6\%) carnivores (two dogs Canis lupus) and six (19\%) omnivores (one brown bear Ursus arctos and five pigs Sus scrofa). Moreover, three (9\%) Aves sp. were also sampled (Table S2). One unique case was the sample TE SSD selected from an entire skeleton of a pig found lying on its right side in a single stoned-lined pit grave (tomb 11) at the site of Terlano in Adige valley.

The age estimation revealed $62(68 \%)$ adults and 29 (32\%) subadults of the 91 human samples. The latter were two perinatal (2\%), three newborn (3\%), 14 infants 1 st $(15 \%)$, seven infants 2 nd $(8 \%)$ and three juveniles (3\%) (Fig. 2). The sex estimation of the adult individuals revealed $38(42 \%)$ males, 20 (22\%) females and four (4\%) individuals that could not be confidently sexed (n.d.), (Fig. 2). Grave goods were recorded in 22 graves of 12 males, six females, one adult of unknown sex and three subadults (Table S1).

\section{Sample quality and descriptive statistics}

Collagen of good quality, according to the criteria for $\delta^{13} \mathrm{C}$ and $\delta^{15} \mathrm{~N}$ values, was recorded in 85 (93\%) human samples. For $\delta^{34} \mathrm{~S}$ values, 40 (44\%) of the humans were considered as good collagen samples (Table S1), and thus, the samples from Nalles and Tanas had to be discarded before statistical analyses, due to their bad quality. The majority of the animals (30/ $32,94 \%$ ) were of good quality and were evaluated for all the stable isotope analyses (Table S2). Descriptive statistics for the faunal and human dataset, without the aforementioned outliers, are presented in Table 1. 


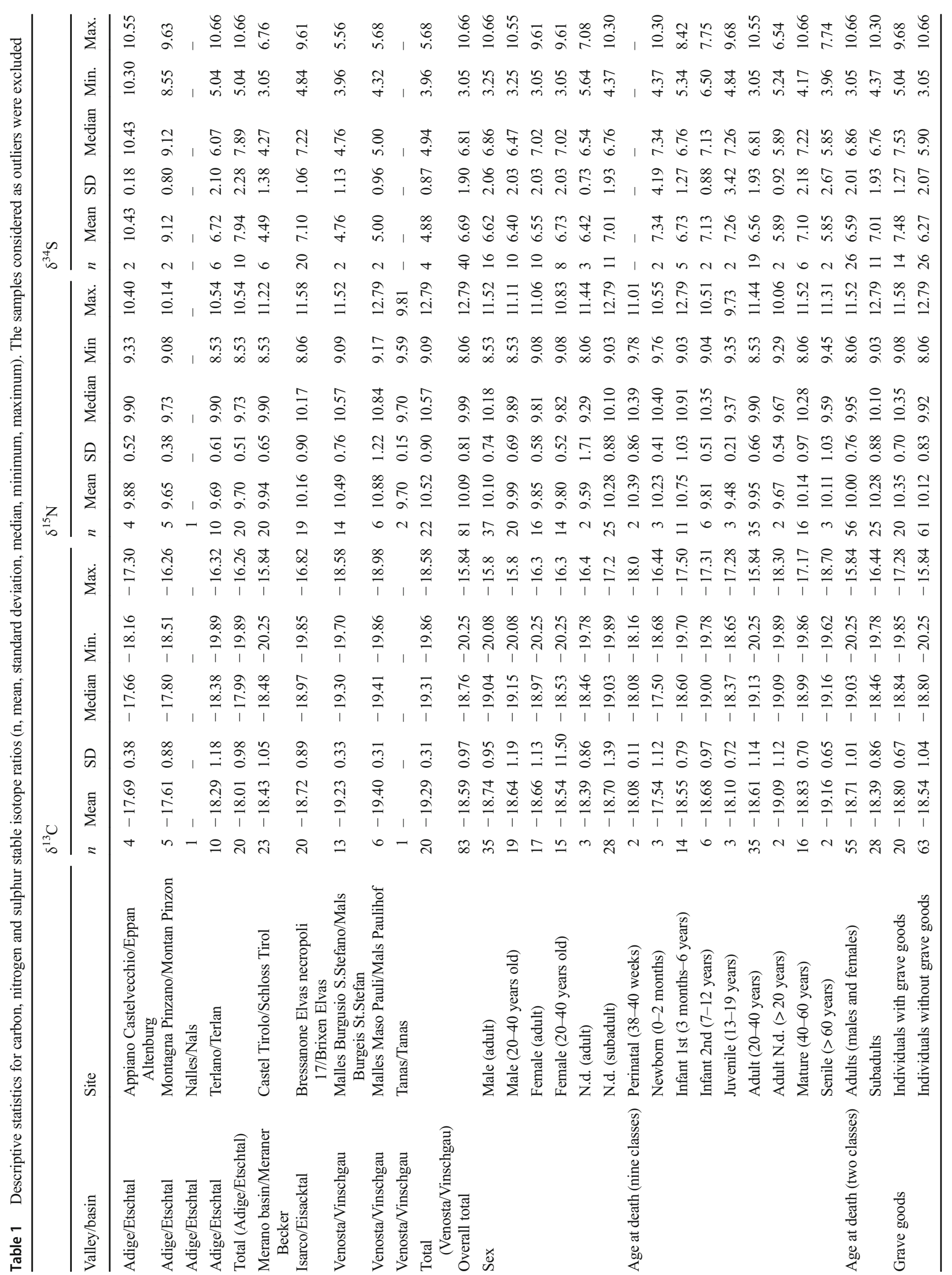




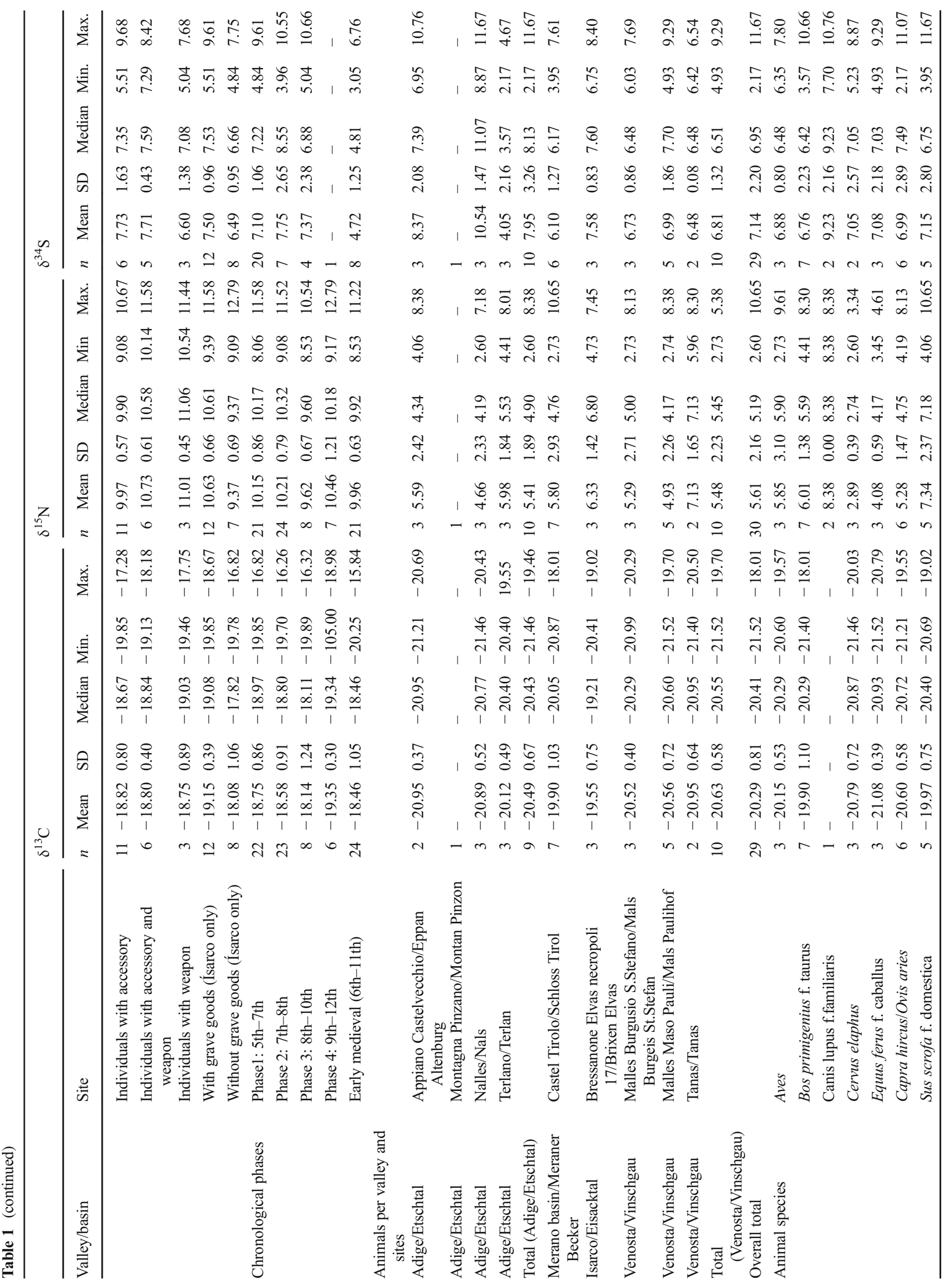


The $\delta^{13} \mathrm{C}$ values for herbivores ranged from -21.52 to $18.01 \%$ (mean $-20.45 \pm 0.89 \%$ o $) ; \delta^{15} \mathrm{~N}$ values ranged from + 2.60 to $+8.30 \%$ (mean $+4.98 \pm 1.61 \%$ ) , and $\delta^{34} \mathrm{~S}$ values ranged from +2.17 to $+11.07 \%$ o (mean $+6.92 \pm 2.28 \%$ o) . The omnivores ranged between -20.69 and $-19.02 \%$ for $\delta^{13} \mathrm{C}$ values (mean $-19.98 \pm 0.67 \%$ ) $; \delta^{15} \mathrm{~N}$ values between +2.73 and $+7.92 \%$ o (mean $+6.57 \pm 2.83 \% 0)$ and $\delta^{34} \mathrm{~S}$ values between 3.95 and $+11.67 \%$ o (mean $+7.22 \pm 2.51 \%$ o). Only one dog (MHP CF) represented the carnivores for $\delta^{13} \mathrm{C}$ values $\left(-19.00 \%\right.$; the outlier for $\delta^{13} \mathrm{C}$ values is $\mathrm{AP}-\mathrm{AL} \mathrm{CF}$, as displayed in Table S2). For $\delta^{15} \mathrm{~N}$ values, both dogs provided the same results $\left(+8.38 \%\right.$ ) , while $\delta^{34} \mathrm{~S}$ values ranged between +7.70 and $+10.76 \%$ o (mean $+9.23 \pm 2.16 \%$ o $)$.

The $\delta^{13} \mathrm{C}$ values of all human samples ranged from -20.25 to $-15.84 \%$, with a mean of $-18.59 \pm 0.97 \%$. The $\delta^{15} \mathrm{~N}$ values ranged from +8.06 to $+12.79 \%$ (mean of $+10.09 \pm$ $0.81 \%$ ) and $\delta^{34} \mathrm{~S}$ values ranged from +3.05 to $+10.66 \%$ o (mean of $+6.69 \pm 1.90 \%$ ) . The highest mean value for $\delta^{13} \mathrm{C}$ in humans was observed in Adige valley (Table 1; Fig. 3a, b), the highest $\delta^{15} \mathrm{~N}$ mean value was in Venosta valley (Table 1; Fig. 3a, b), and the $\delta^{34} \mathrm{~S}$ data showed the highest mean in Adige valley (Table 1, Fig. 3c, d). Figure 4a-c show the stable isotope variations based on altitudes in more detail. The highest mean values for $\delta^{13} \mathrm{C}$ were detected at lower altitudes around $400 \mathrm{~m}$ a.s.l. (Fig. $4 \mathrm{a}$ ), as well as for $\delta^{34} \mathrm{~S}$ data (Fig. $4 \mathrm{~b}$ ). This was different for the $\delta^{15} \mathrm{~N}$ values, where the highest means corresponded to altitudes around $1000-1300 \mathrm{~m}$ a.s.l. (Fig. 4c).

All adults (males and females) of the different valleys ranged from -20.25 to $-15.84 \%$, with a mean of $18.71 \pm 1.01 \%$ o for $\delta^{13} \mathrm{C}$ values (Table 1). In Venosta valley, the females $(-19.59 \pm 0.28 \%$ o $)$ displayed slightly lower $\delta^{13} \mathrm{C}$ values compared to the males $(-19.20 \pm$ $0.28 \%$ ) (Fig. 5a). Concerning the $\delta^{15} \mathrm{~N}$ mean values, the females represented the lowest means compared to males and subadults. The subadults from Isarco valley, differently from the other areas, showed a lower $\delta^{15} \mathrm{~N}$ mean values $(+10.04 \pm 1.13 \%$ ) compared to the males $(+10.34 \pm 0.68 \%$ o $)$ (Fig. 5a). The $\delta^{34} \mathrm{~S}$ data showed that females in Adige valleys had higher values than males, while in Isarco valley, the values were more equal. However, no comparisons among sexes could be considered for Merano basin and Venosta valley due to the limited number of samples with collagen of good quality for $\delta^{34} \mathrm{~S}$ values (Fig. 5b).

Four different groups, according to the presence of grave goods, were also clustered (Table 1; Fig. 6a, b): (1) individuals buried with accessory (e.g. parts of belt, jewelry), (2) accessory and weapon, (3) weapon only and (4) without any grave goods. The mean of the $\delta^{13} \mathrm{C}$ values between groups showed little variations with the means ranging between -18.82 and $-18.75 \%$. However, individuals buried with weapons showed the highest mean values for $\delta^{15} \mathrm{~N}$ (Fig. 6 a), while 
Table 2 List of $p$ values of one-way ANOVA and independent sample $t$ tests. The significance level set at 0.05 and significant values are shown in italics

\begin{tabular}{|c|c|c|c|c|c|c|}
\hline & \multicolumn{2}{|l|}{$\delta^{13} \mathrm{C}$} & \multicolumn{2}{|l|}{$\delta^{15} \mathrm{~N}$} & \multicolumn{2}{|l|}{$\delta^{34} \mathrm{~S}$} \\
\hline & \multicolumn{2}{|l|}{$p$ value } & \multicolumn{2}{|l|}{$p$ value } & \multicolumn{2}{|l|}{$p$ value } \\
\hline & ANOVA & Independent $t$ test & ANOVA & Independent $t$ test & ANOVA & Independent $t$ test \\
\hline Valleys & 0.000 & - & 0.007 & - & 0.000 & - \\
\hline Adige vs Merano basin & 0.548 & - & 0.744 & - & 0.000 & - \\
\hline Adige vs Isarco & 0.097 & - & 0.242 & - & 0.474 & - \\
\hline Adige vs Venosta & 0.000 & - & 0.005 & - & 0.007 & - \\
\hline Merano vs Isarco & 0.754 & - & 0.810 & - & 0.003 & - \\
\hline Merano vs Venosta & 0.005 & - & 0.077 & - & 0.977 & - \\
\hline Isarco vs Venosta & 0.056 & - & 0.440 & - & 0.047 & - \\
\hline Sites (Nalles and Tanas excluded) & 0.000 & - & 0.028 & - & 0.000 & - \\
\hline Sexes (males, females and n.d. subadults) & 0.343 & - & 0.221 & - & 0.845 & - \\
\hline Males vs females & - & 0.799 & - & 0.235 & - & 0.931 \\
\hline $\begin{array}{l}\text { Males (adults } 20-40 \text { years) vs females } \\
\text { (adults } 20-40 \text { years) }\end{array}$ & - & 0.819 & - & 0.375 & - & 0.712 \\
\hline $\begin{array}{l}\text { Males (adults } 20-40 \text { years) vs females } \\
\text { (adults } 20-40 \text { years) Adige }\end{array}$ & - & 0.963 & - & 0.030 & - & 0.746 \\
\hline $\begin{array}{l}\text { Males (adults } 20-40 \text { years) vs females } \\
\text { (adults 20-40 years) Isarco }\end{array}$ & & 0.691 & & 0.571 & & 0.653 \\
\hline $\begin{array}{l}\text { Males (adults } 20-40 \text { years) vs females } \\
\text { (adults 20-40 years) Venosta }\end{array}$ & & 0.459 & & 0.483 & & $\begin{array}{l}\text { Insufficient data } \\
\text { quantity }\end{array}$ \\
\hline Males (matures) vs females (matures) & - & $\begin{array}{l}\text { Insufficient data } \\
\text { quantity }\end{array}$ & - & $\begin{array}{l}\text { Insufficient data } \\
\text { quantity }\end{array}$ & - & $\begin{array}{l}\text { Insufficient data } \\
\text { quantity }\end{array}$ \\
\hline Males (seniles) vs females (seniles) & - & $\begin{array}{l}\text { Insufficient data } \\
\text { quantity }\end{array}$ & - & $\begin{array}{l}\text { Insufficient data } \\
\text { quantity }\end{array}$ & - & $\begin{array}{l}\text { Insufficient data } \\
\text { quantity }\end{array}$ \\
\hline Age classes (adults vs subadults) & - & 0.149 & - & 0.156 & - & 0.526 \\
\hline Grave goods present vs absent & - & 0.297 & - & 0.105 & - & 0.054 \\
\hline Grave goods present vs absent (Isarco only) & - & 0.025 & - & 0.001 & - & 0.033 \\
\hline Chronological phases & 0.004 & - & 0.270 & - & 0.982 & - \\
\hline Phase 1 vs phase 2 & 0.918 & - & - & - & - & - \\
\hline Phase 1 vs phase 3 & 0.594 & - & - & - & - & - \\
\hline Phase 1 vs phase 4 & 0.055 & - & - & - & - & - \\
\hline Phase 2 vs phase 3 & 0.794 & - & - & - & - & - \\
\hline Phase 2 vs phase 4 & 0.011 & - & - & - & - & - \\
\hline Phase 3 vs phase 4 & 0.108 & - & - & - & - & - \\
\hline
\end{tabular}

the two groups "accessory" and "accessory and weapon" resulted in higher $\delta^{34} \mathrm{~S}$ mean values compared to the other clusters (Fig. 6b).

A clustering based on the chronological phases was also evaluated (Fig. 7a, b). The highest mean value of $\delta^{13} \mathrm{C}$ was represented by the group of phase 3 (Table 1; Fig. 7a, b); the highest mean value for $\delta^{15} \mathrm{~N}$ by the group of phase 4 (Table 1; Fig. 7a), while the highest $\delta^{34} \mathrm{~S}$ mean value was displayed for the human individuals of phase 2 (Table 1; Fig. 7b).

Non-migratory animals, such as domestic pigs (Scheeres et al. 2013), were used as a faunal baseline to detect the presence of possible allochthonous individuals in Adige valley as displayed in Fig. 8.

\section{Statistical tests}

The valleys and the archaeological sites showed significant differences in all stable isotope elements (Table 2). Moreover, the results showed differences in $\delta^{13} \mathrm{C}$ between Adige and Venosta valley (post-hoc ANOVA, $p$ value $=$ 0.000 ) and Merano basin vs Venosta valley (post-hoc ANOVA, $p$ value $=0.005)$. Differences in $\delta^{15} \mathrm{~N}$ values were significant in Adige vs Venosta valley (post-hoc ANOVA, $p$ value $=0.005$ ). The $\delta^{34} \mathrm{~S}$ values were significantly different in Adige valley vs Merano basin (post-hoc ANOVA, $p$ value $=0.000)$ and Venosta (post-hoc ANOVA, $p$ value $=$ 0.007 ) as well as in Merano basin vs Isarco valley (post-hoc 


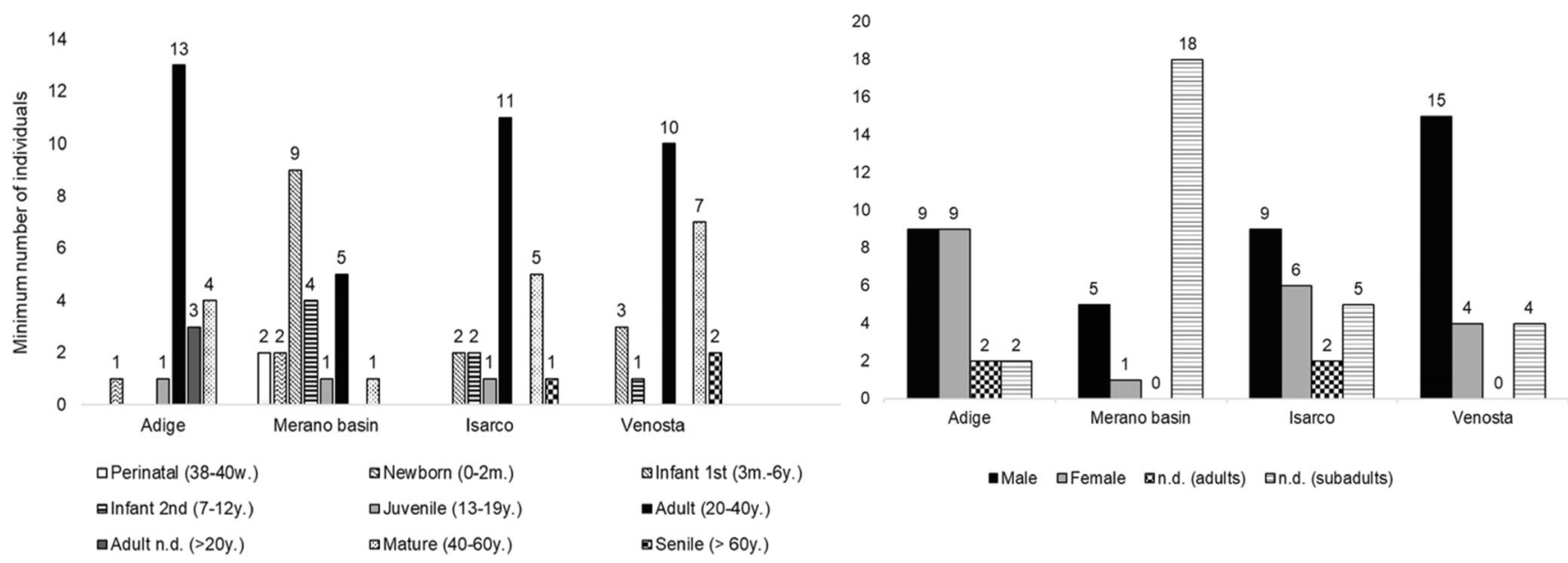

Fig. 2 Age at death (left) and sex (right) distribution of all the human individuals $(n=91)$ grouped by valleys/basin

ANOVA, $p$ value $=0.003$ ) and the latter vs Venosta valley (post-hoc ANOVA, $p$ value $=0.047$ ). There were no differences of all stable isotopes elements between males, females and subadults overall. However, statistical differences were observed for $\delta^{15} \mathrm{~N}$ values of males and females (adults 2040 years) from Adige valley (independent $t$ test, $p$ value $=0.030$ ) only.

The individuals buried with or without grave goods did not displayed statistical differences (Table 2). However, if only the site of Bressanone Elvas was tested, significant differences among the two groups in all the analysed isotope values were observed (independent $t$ test, for $\delta^{13} \mathrm{C} p$ value $=0.025 ;$ for $\delta^{15} \mathrm{~N} p$ value $=0.001 ;$ for $\delta^{34} \mathrm{~S} p$ value $=0.033$ )

The chronological phases displayed differences only in the $\delta^{13} \mathrm{C}$ values for phase 2 vs phase 4 (post-hoc ANOVA, $p$ value $=0.011)$.

\section{Discussion}

\section{Fauna in Early medieval South Tyrol}

The isotopic results reflected a terrestrial based diet with a $\mathrm{C}_{3}$ plant intake. In order to obtain a proper baseline for $\delta^{13} \mathrm{C}$ and $\delta^{15} \mathrm{~N}$ stable isotopes, different animal remains, including domesticated and wild animals, were considered (Katzenberg 2008; Bonafini et al. 2013). Both forested species (bear and deer) showed relatively negative $\delta^{13} \mathrm{C}$ values as expected, although no significant differences in the other herbivores were detected. The reason for this ${ }^{13} \mathrm{C}$-depletion can be explained by the so-called canopy effect, which is caused by ${ }^{13} \mathrm{C}$-depleted plants and a gradient of leaf $\delta^{13} \mathrm{C}$ values from ground to canopy in a dense woodland ecosystem (Bonafini et al. 2013; Drucker et al. 2008, 2011; Ferrio et al. 2003; Van der Merwe and Medina 1991). Interestingly, the horses presented the most negative $\delta^{13} \mathrm{C}$ mean $(-21.08 \pm 0.39 \%$; Fig. $3 \mathrm{~b})$ together with the most representative forest animals, such as deers $(-20.79 \% \circ \pm 0.72 \%$; Fig. 3a, b), suggesting that they were fed in forested enviroments or other places depleted in ${ }^{13} \mathrm{C}$. This is comparable with the low $\delta^{13} \mathrm{C}$ mean value ($22.1 \pm 0.4 \%$ o) of the horses from central medieval Germany, probably due to environmental factors (e.g. mixed habitats) as well as metabolic differences (Knipper et al. 2012). As expected, the $\delta^{15} \mathrm{~N}$ values of all faunal remains showed the highest variation (from +2.60 to $+10.65 \%$ ). The $\delta^{15} \mathrm{~N}$ mean value of the dogs was enriched by $\Delta 3.4 \%$ o compared to the herbivore average. However, the dogs had lower nitrogen values $(+8.38$ $\pm 0.00 \%$ o compared to the humans $(+10.09 \pm 0.81 \% o)$, suggesting an omnivore diet. An explanation for this could be that dogs, as human companions, were likely provisioned with human refuses. Indeed, stable isotopes from dogs remains can offer indication of their owners' dietary habits (Guiry 2012). This might also be confirmed by the $\delta^{13} \mathrm{C}$ values, with a clear $\mathrm{C}_{4}$ signal $(-16.36 \%$ ) for the dog sample (AP-AL CF, a statistical outlier) found in Adige. Differently to the dogs, the pigs in Adige valley might have been fed not only with leftovers, but also with a greater ammount of $\mathrm{C}_{3}$ plants (e.g. oakwood, acorn). Anagously, the pigs' nitrogen values (+ $6.91 \pm 1.9 \%$ o from the medieval site of Petersberg in South Germany, showed an herbivore diet (Lösch 2009). This is in accordance with Early medieval farming practices, as domesticated pigs were possible allowed out to grass in open lands and/or forests (Montanari and Baruzzi 1981). The highest $\delta^{15} \mathrm{~N}$ value $(+10.65 \%$ ) of a young pig (TCT SSD) indicated that it was buchered or it died before weaning. Another relatively high $\delta^{15} \mathrm{~N}$ value $(+8.01 \%$ ) was observed from a pig (TE SSD), which was found in a single stoned-lined pit grave (tomb 11) in Terlano. The trophic level is similar to the local humans, and this pig's single burial might have had a ritualistic purpose, as already documented in the second century BC (Marcus Porcius Cato, De Agri Cultura). The lowest $\delta^{15} \mathrm{~N}$ 

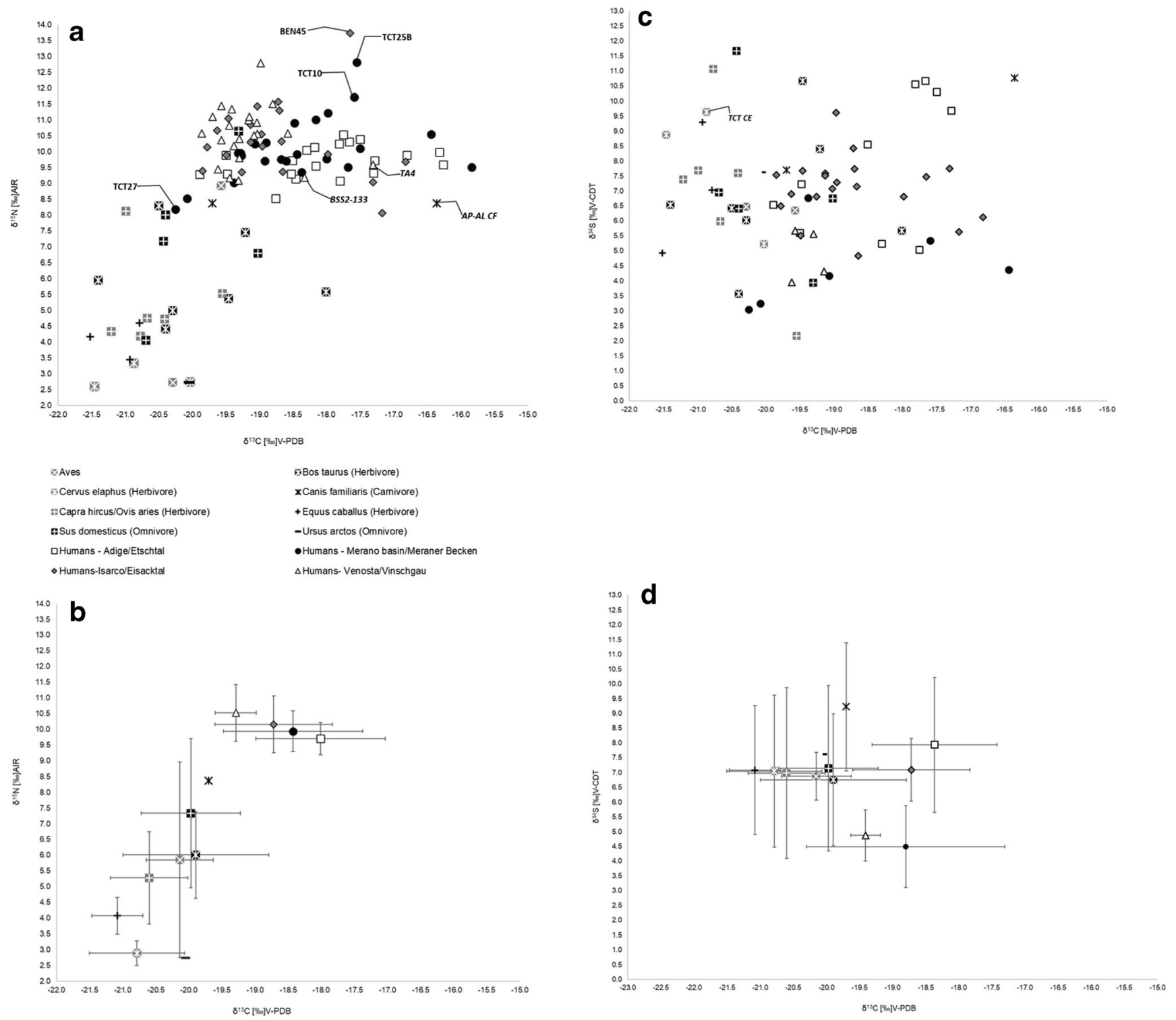

Fig. 3 a Plotted results of $\delta^{13} \mathrm{C}$ and $\delta^{15} \mathrm{~N}$ values of all human $(n=85)$ and animal samples $(n=30)$ with collagen of good quality. The statistical outliers are indicated (Italics = outliers for the $\delta^{14} \mathrm{C}$ values only). $\mathbf{b}$ Mean $\delta^{13} \mathrm{C}$ and $\delta^{15} \mathrm{~N}$ values, excluding the outliers, with SD. $\mathbf{c}$ Plotted

results of $\delta^{13} \mathrm{C}$ and $\delta^{34} \mathrm{~S}$ values of all human $(n=40)$ and animal $(n=30)$ with collagen of good quality. The statistical outlier for $\delta^{34} \mathrm{~S}$ value is indicated in italics. d Mean $\delta^{13} \mathrm{C}$ and $\delta^{34} \mathrm{~S}$ values, excluding the outliers, with SD

values were observed from samples of red deer and brown bear, such as +2.60 and $+2.73 \%$ o respectively. Regarding the isotopic signature of the bear, the hybernatic metabolic process could explain the isotopic depleted nitrogen value which was also reported for a medieval brown bear (+ $1.10 \%$ o) by Lösch (2009). A significant difference in the metabolism of modern black bears (Ursus americanus) and grizzly bear (A. arctos) compared to other animals has been documented (Nelson et al. 1998). During that process, the bears maintain their body temperature with no defecation nor urination. According to Bocherens et al. (2006), depleted $\delta^{15} \mathrm{~N}$

values could also indicate a herbivore diet or that the bear suffered long cold climatic conditons.

\section{Varying dietary patterns in Early medieval valleys in South Tyrol}

The overall stable isotope data indicated a terrestrial diet with a subsistence base of mainly $\mathrm{C}_{3}$ plants for all human samples across the different valleys. The $\mathrm{C}_{3}$-signal is in accordance with published studies of medieval populations in western and central Europe (e.g. Hakenbeck et al. 2010, 2017; Knipper et al. 2012; 

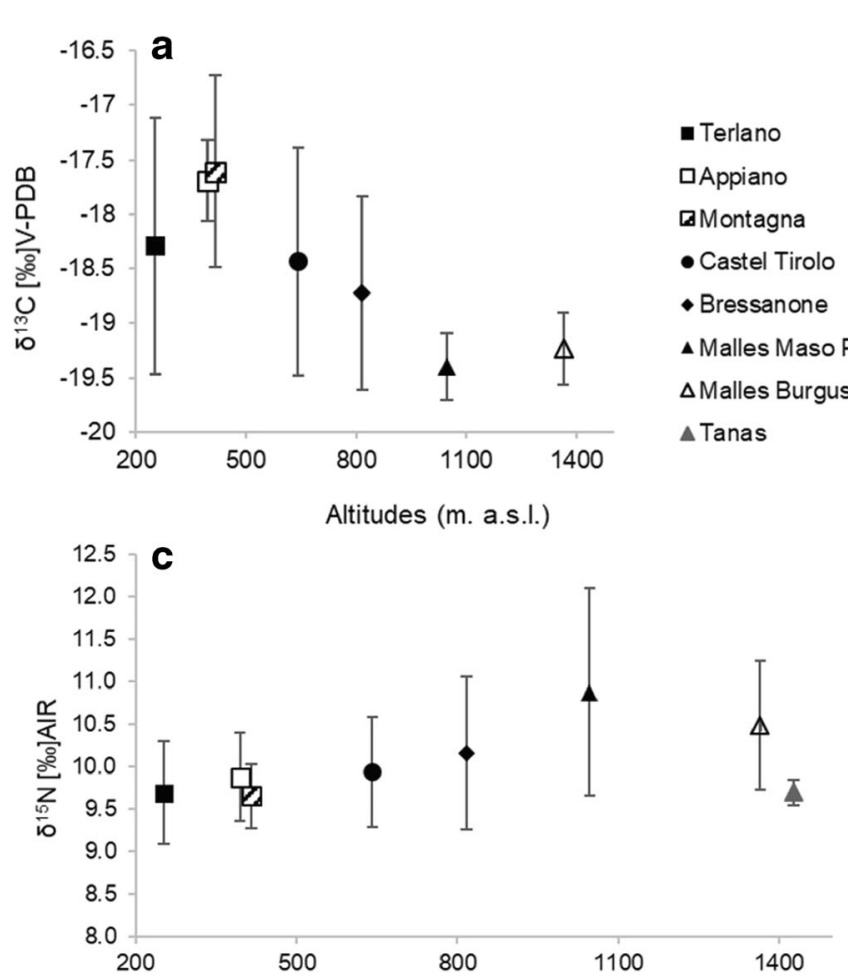

Fig. 4 a Plotted $\delta^{13} \mathrm{C}$ mean values (including $\mathrm{SD}$ ) in relation to altitudes ( $\mathrm{m}$ a.s.l) for the archaeological sites (excluding Nalles and Tanas) and valleys (squares $=$ Adige valley, circles $=$ Merano basin, diamonds $=$ Isarco valley, and triangle $=$ Venosta valley). $\mathbf{b}$ Plotted $\delta^{34} \mathrm{~S}$ mean

Prevedorou et al. 2010; Polet and Katzenberg 2003; Reitsema et al. 2010; Reitsema and Vercellotti 2012; Schutkowski and Herrmann 1999). The data showed significant differences in diet among the populations from the valleys, whereby the $\delta^{13} \mathrm{C}$ and $\delta^{15} \mathrm{~N}$ data differed most between the individuals from Adige valley and those from Venosta valley (Fig. 3a, b). The Italian Alps consist of highly diverse geological areas, including these two valleys in particular, which are located in different regional zones and at various altitudes (Figs. $1 \mathrm{~b}$ and $4 \mathrm{a}, \mathrm{c}$ ). The results showed depleted $\delta^{13} \mathrm{C}$ values (mean $\Delta 1.3 \%$ ) and enriched $\delta^{15} \mathrm{~N}$

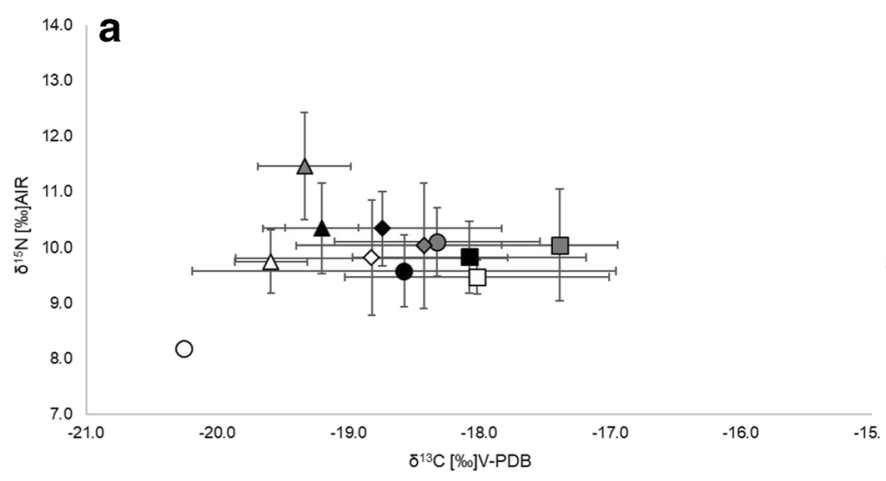

Fig. 5 a Plotted $\delta^{13} \mathrm{C}$ and $\delta^{15} \mathrm{~N}$ mean values (total $n=79$ excluding the six outliers as shown in Table S1) and SD for males, females, and subadults grouped by valleys. b Plotted $\delta^{13} \mathrm{C}$ and $\delta^{34} \mathrm{~S}$ mean values (including SD) for males, females, and subadults (total $n=40$ ) grouped

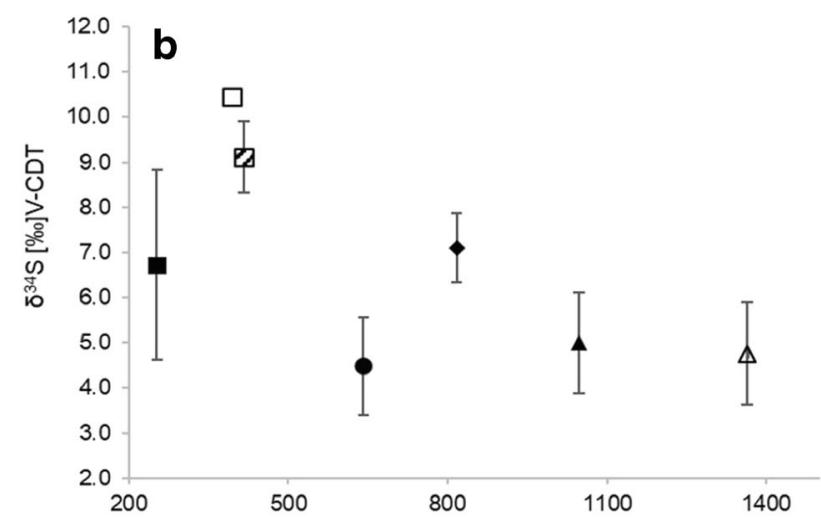

values (including SD) in relation to altitudes ( $m$ a.s.1.) for the archaeological sites (excluding Nalles and Tanas) and valleys. c Plotted $\delta^{15} \mathrm{~N}$ mean values (including SD) in relation to altitudes ( $\mathrm{m}$ a.s.l.) for the archaeological sites (excluding Nalles) and valleys

values (mean $\Delta 0.8 \%$ ) in Venosta valley compared to Adige valley (Table 1). The observed values could be due to the availability and use of different food sources at different altitudes; however, anthropogenic effects such as manuring or admixing food sources from different geographical locations have to be considered. Moreover, the data could also indicate that the cultivation of $\mathrm{C}_{4}$ plants played an important role. Remains of $\mathrm{C}_{4}$ cereals dating to Copper Age were already recovered at sites located at 700-850 $\mathrm{m}$ a.s.l. in Isarco valley (Castiglioni and Tecchiati 2005; Festi et al. 2011; Nisbet 2008). At the burial site

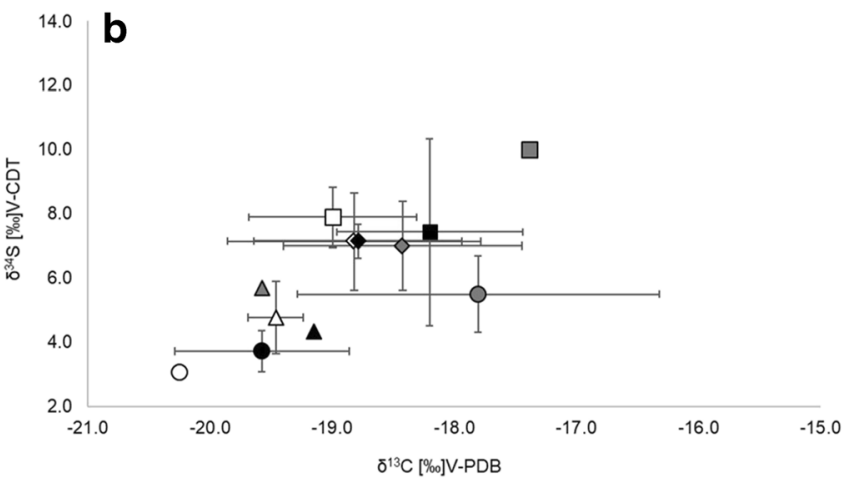

by valleys. White $=$ females, black $=$ males, and gray $=$ subadults. Squares = Adige valley, circles = Merano basin, diamonds = Isarco valley, and triangle $=$ Venosta valley 

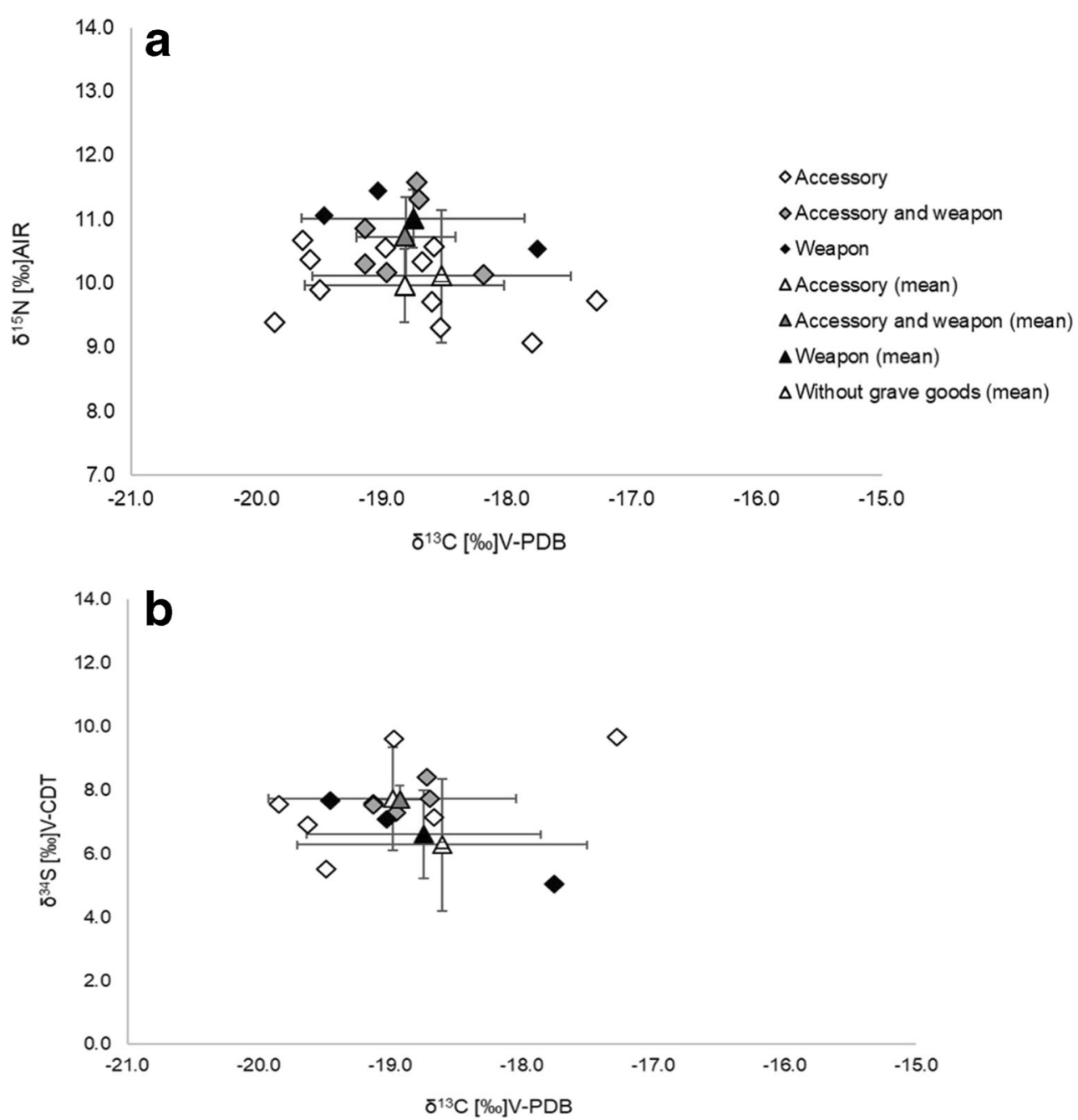

Fig. 6 a Plotted $\delta{ }^{13} \mathrm{C}$ and $\delta{ }^{15} \mathrm{~N}$ mean values (including SD) of the samples grouped according to the four groups of graves goods. Graves without goods are only represented by their mean value (including SD). b
Plotted $\delta{ }^{13} \mathrm{C}$ and $\delta^{34} \mathrm{~S}$ mean values (including SD) of the samples grouped according to the four groups of graves goods. Graves without goods are only represented by their mean value (including SD) of Naz, next to Bressanone Elvas in the Isarco valley, carbonized cereals were found in graves (Kaufmann and Demetz 2004) including spelt (Triticum spelta), barley (Hordeum vulgare) but also few remains of $\mathrm{C}_{4}$ plants like millet as well as fruit seeds and grapevine (Vitis vinifera) (Öggl 1993). In the present study, the $\mathrm{C}_{4}$ plant intake had a bigger influence on the diet at lower altitudes (Adige valley) compared to higher altitudes. In total, 53\% $(n=10 / 19)$ of the individuals from Adige valley expressed $\delta^{13} \mathrm{C}$ values more positive than $-18 \%$ and thus a signal of an intake of $\mathrm{C}_{4}$ plants, such as millet or sorghum (Le Huray and Schutkowski 2005). Given the important contribution of fruits and seeds in the nowadays diet in South Tyrol, the isotopic variability among different botanical species has to be considered. Indeed, the observed $\delta^{13} \mathrm{C}$ values may also indicate a contribution of, e.g. fruits, seeds, roots and woody stems, which are ${ }^{13} \mathrm{C}$-enriched compared to leaves and thus lead to more positive $\delta^{13} \mathrm{C}$ values in the consumers' tissue (Cernusak et al. 2009). In Merano basin 25\% ( $n=$ $6 / 24)$, in Isarco valley $20 \%(n=4 / 20)$ and in Venosta valley only
$5 \%(n=1 / 22)$ of the individulas indicate a $\mathrm{C}_{4}$-signal. This suggests an increased significance of $\mathrm{C}_{4}$ plant cultivation at lower altitudes compared to settlements at higher areas. However, trading might have played a key role in nutrition preferences and communications among valleys influencing cultivation patterns of neighbouring regions. Indeed, since Roman times, transalpine trading routes, such as Via Claudia Augusta, crossed this territory between northern Italy and the transalpine areas into Augusta Vindelicorum (Augsburg) in southern Germany and thus connecting the valleys from the southern to northern areas of the region and favouring goods exchanges (Banzi 2005; Kustatscher and Romeo 2010). Therefore, trading and communication between the valleys, as well as within neighbouring territories, could have led to human adaptation and changes in agriculture. In addition, mobility pattern could also be an explanation for the $\mathrm{C}_{4}$ signal of two individuals found at higher altitudes (BSS2-133 and TA4), although a general decrease of the $\mathrm{C}_{4}$ signal at higher areas was recorded. 

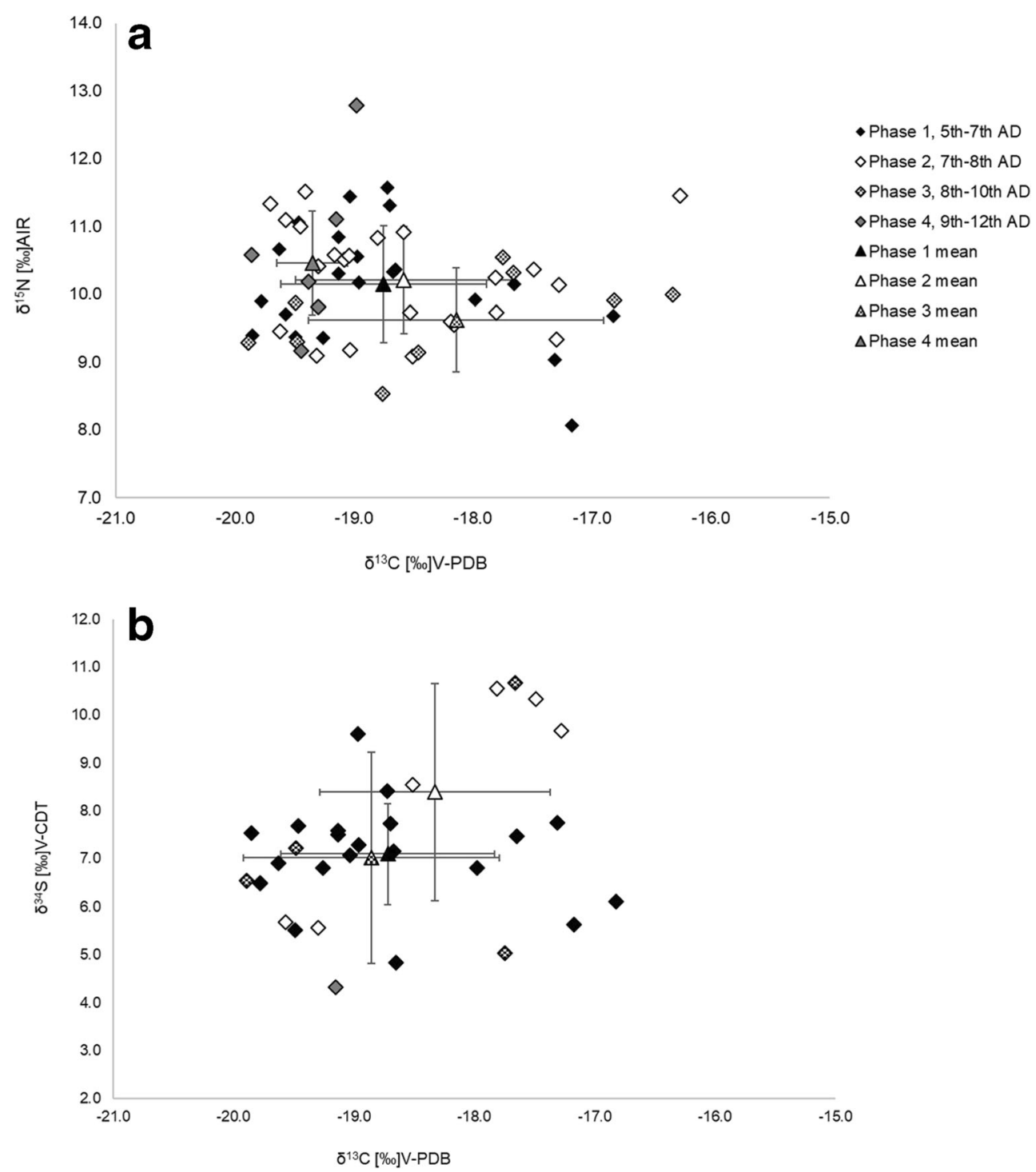

Fig. 7 a Plotted $\delta^{13} \mathrm{C}$ and $\delta^{15} \mathrm{~N}$ mean values (including SD) of the samples grouped according to the four chronological phases. b Plotted $\delta^{13} \mathrm{C}$ and $\delta^{34} \mathrm{~S}$ mean values (including SD) of the samples grouped according to the four chronological phases

Unfortunately, the carbon stable isotope data presented in this work cannot be compared with other local datasets; as to the authors' knowledge, there is a clear lack of available comparative data from Trentino-South Tyrol. Published comparable data from southern German medieval Petersberg (Lösch 2009) and Austrian Early medieval Volders (McGlynn 2007) were used for comparisons. As expected, our data showed higher variation in $\delta^{13} \mathrm{C}$, compared not only to Volders (males $-20 \pm 0.4 \%$ and females $-20 \pm 0.4 \%$ ) but also to Petersberg (males $-20.5 \%$ ond females $-20.5 \%$ ), and to other sites in Bavaria (Knipper et al. 2012). This is mainly due to the variety of geographical areas considered in this paper, whereas Petersberg and Volders represent samples from a single site. The diversity of the carbon values can also be explained by climatic variations in South Tyrol that allow differences of plant cultivation and human adaptation to the enviroment. The enviromental and climatic conditions influenced the types of cultivation during the different chronological phases within the valleys. The highest $\delta^{13} \mathrm{C}$ mean value $(-18.14 \pm 1.24 \%$ o $)$ corresponded to the chronological phase 3 (eighth-tenth centuries AD) (Table 1; Fig. 7a). This result could indicate a possibile increased consuption of $\mathrm{C}_{4}$ plants due to favourable climatic conditions, since this period corresponded to a climatic optimum characterized by warmer climat (Hughes and Diaz 1994; Mann et al. 2009).

The stable nitrogen isotopic data indicated a higher intake of animal protein, such as meat and dairy products, at higher altitudes, with the highest mean value of $\delta^{15} \mathrm{~N}(+10.52 \pm$ $0.90 \%$ ) in Venosta, followed by Isarco valley $\left(\delta^{15} \mathrm{~N}+10.16\right.$ $\pm 0.90 \%$ ). Overall, the $\delta^{15} \mathrm{~N}$ averages of the humans were enriched by $\Delta 5.1 \%$ o compared to herbivores, displaying a difference of one trophic level (Hedges and Reynard 2007). Two adults, one from Venosta (BSS7-105A) and one from 
Isarco valley (BEN18) showed enriched $\delta^{15} \mathrm{~N}$ values (Table S1), which could be due to a lower proportion of herbivore meats $(\Delta 6.4 \%$ ) in favour of omnivore meats, as also suggested by Knipper et al. (2012). Another explanation could be that these individuals (one male and one n.d.) had more in general a significant higher proportion of animal proteins in their diet compared to the other individuals of the same sites. Therefore, this could be an indicator of higher social status, as animal ressources were much more expensive to produce. Consumption of dairy products is the other possible cause of higher $\delta^{15} \mathrm{~N}$ values in humans. In Northern Italy, cheese was traditionally made with sheep or goats' milk (Flandrin and Montanari 2007). In the Alpine areas, cow milk was also used, as documented by the earlier evidences of dairy lipids in Iron Age vessels (Carrer et al. 2016).

\section{Geological differences and mobility patterns in Early medieval South Tyrol}

The isotopic variation of the $\delta^{34} \mathrm{~S}$ values of humans $(n=40)$ ranged from +3.05 to $+10.66 \%$ o (mean $+6.69 \pm 1.90 \%$ o). In Adige valley, the human $\delta^{34} \mathrm{~S}$ values ranged from +5.04 to + $10.66 \%$ o (mean $+7.94 \pm 2.28 \%$ ) displaying the higher standard deviation $( \pm 2.28 \%$ ) compared to the other territories (Table 1). This might be explained by different hypotheses, such as (i) variation in dietary habits, (ii) different geological factors, (iii) mobility patterns. (i) A certain proportion of freshwater fish as a food source might be considered, due to the proximity to freshwater sources, and the finding of archaeological materials (e.g. hooks) would also suggest fishing in this area (Dal Ri 2009; Tecchiati 2009). However, at the present, there are still no available freshwater fish data from that area; thus, further conclusion on fish consumption in Early medieval South Tyrol cannot be made. (ii) The drinking water, as well as other nutritional sources, could have been enriched in sulphur, due to the presence of the aforementioned sulphurous water springs (Lunz 1974; Tecchiati and Zanforlin 2010). Nevertheless, other analyses are needed to better understand the implication of those springs to the local sulphur values. (iii) Based on the human values, there are some distinct differences between Adige and the other sites with enriched and varying $\delta^{34} \mathrm{~S}$ values in Adige. An explanation might be some mobility pattern (Vika 2009; Richards et al. 2001). The study of Coia et al. (2012) reported already a higher genetic diversity in modern populations in Adige compared to other valleys in Trentino, probably indicating that different populations went through Adige valley since prehistory. This was also documented by local archaeological data (Lanzinger et al. 2000). Due to the different sample sizes of the faunal remains per valley, the local baseline for Adige valley could be established based on non-migratory animals (pigs) (Fig. 8). The $\delta^{34} \mathrm{~S}$ mean value of the three pigs from Adige $(+8.34 \%$ o $\pm 2.89 \%$ o $)$ showed a slightly more positive rate compared to the humans $(\Delta 0.4 \%$ ). However, two individuals from the site of Terlano (TE7 and TE-sett.A1) showed lower values to the faunal baseline (5.04\%o and 5.24\%o respectively) and a difference of $\Delta 3.2 \%$, and thus a possible different origin and/or a change in dietary habits is suggested. Of particular interest is the adult male TE7, as he was the only Early medieval individual in Terlano inhumated with a grave good (i.e. sharp object). However, the low sample size of non-migratory animals has to be considered and further baseline samples are required to verify the observations on possible migration.

Regarding the chronological phases, the highest $\delta^{34} \mathrm{~S}$ standard deviation $( \pm 2.65 \%$ ) was recorded for phase 2 (seventh-eighth centuries AD), suggestive of greater human mobility during those centuries (Fig. 7b), and this would be in accordance with the few historical and
Fig. 8 Plotted $\delta^{13} \mathrm{C}$ and $\delta^{34} \mathrm{~S}$ values of the humans from Adige valley. The $\delta^{34} \mathrm{~S}$ mean and SD of the pigs from the same site are indicated by the dashed lines representing the local baseline

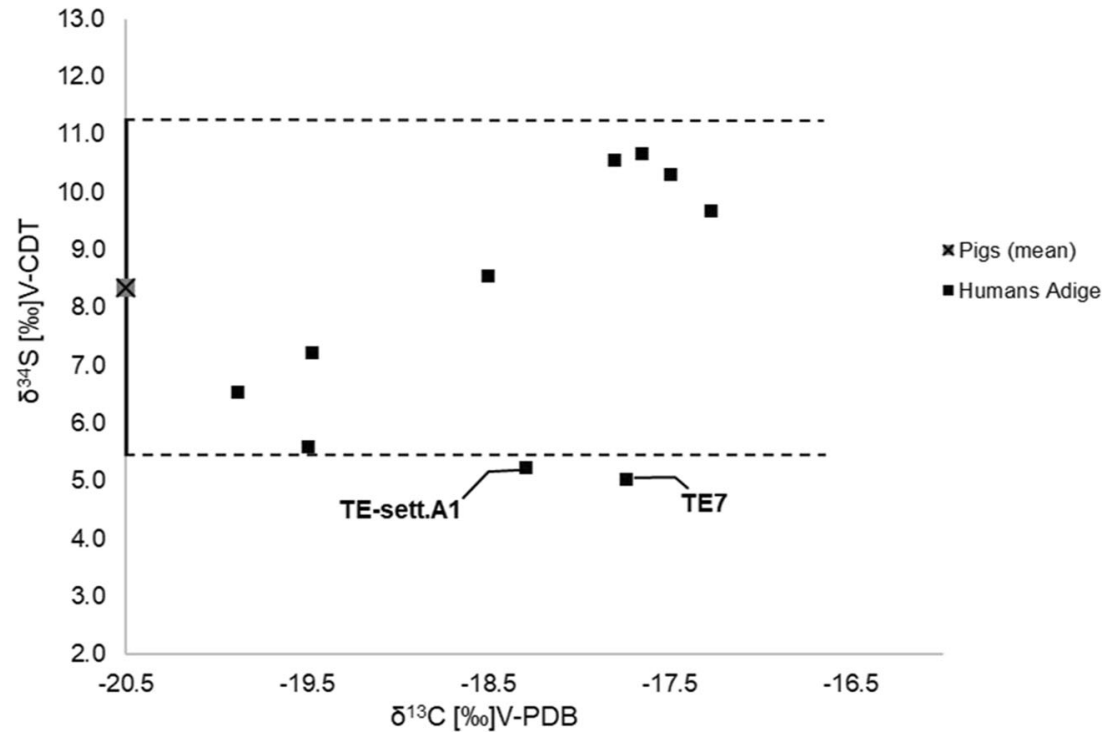


archaeological sources. Particularly from the seventh century, allochthonous cultures (e.g. Langobards, Bavarians) were well-established in the territory, and the archaeological material indicates a cultural hybridity among autochthonous (christianized) and allochthonous traditions (Bierbrauer 2005). However, the tests did not show statistical differences when considering all phases (Table 2). Moreover, the radiocarbon dating was limited to $10 \%$ $(n=4 / 40)$ of the samples with good quality collagen for $\delta^{34} \mathrm{~S}$ analyses (Table $\mathrm{S} 1$ ).

\section{Varying social status and grave goods}

The higher $\delta^{15} \mathrm{~N}$ mean values in males compared to females (Table 1) could suggest sex related restrictions in the access to animal proteins, such as meat and dairy products with males as main consumers. This could also reflect diverse social positions, such as higher social ranks for male individuals (e.g. Czermak et al. 2006; Schutkowski and Herrmann 1999; Moghaddam et al. 2016). However, the nitrogen values of all males against females, independently from their age group, were not statistically significant (Table 2). Differences were observed when $\delta^{15} \mathrm{~N}$ values were tested based on sex in correlation with age classes, but only for Adige valley. In fact, the difference between males and females aged 20-40 years was statistically significant $(p=0.030$; Table 2). This could be indicative of sex-specific dietary differences in this area, with males (20-40 years old) having a diet more rich in animal proteins (mean +9.99 $\pm 0.69 \%$ ) compared to females $(+9.80 \pm 0.52 \%$ o). This is also in accordance with studies on prehistoric and historic populations, suggesting that males had a larger amount of meat and dairy product components in their diets (Moghaddam et al. 2016, 2018; Reitsema et al. 2010; Baldoni et al. 2016). However, when looking at isotopic differences between sexes, the metabolic variations as well as the different bone turnover rates in skeletal elements need to be considered (Fahy et al. 2017; Olsen et al. 2014).

The presence and the type of grave goods might also provide information about sex-specific dietary differences and/or social status (Le Huray and Schutkowski 2005). In the present study, the cemetery of Bressanone Elvas displayed the highest amount of grave goods compared to the other sites. Six males, four females, one adult n.d. and one infant were buried with goods and showed significantly increased $\delta^{15} \mathrm{~N}$ values $(+10.63 \pm 0.66 \%$ o compared to those without any grave goods (two males, one females, one possibile female, three subadults; mean + $9.37 \pm 0.69 \%$ ) (Table 1). This may be due to a higher number of males, with in general higher $\delta^{15} \mathrm{~N}$ mean values $(+10.10 \pm 0.74 \%$ ) in respect to females $(+9.85 \pm$
$0.58 \%$ o). Indeed, in Bressone Elvas, the majority of the individuals buried with weapons (e.g. knife, dagger) were males $(57 \%, 4 / 7)$, and this could suggest not only sex specific dietary differences, with males having a more prestigious role, as reported in other studies (e.g. Le Huray and Schutkowski 2005, Moghaddam et al. 2018), but also a division based on social status, with the "weaponry group" having an increased amount of animal protein in their diet.

\section{Conclusions}

The analyses of $\delta^{15} \mathrm{~N}, \delta^{13} \mathrm{C}$ and $\delta^{34} \mathrm{~S}$ data of human and faunal remains from three different valleys and one basin in South Tyrol were an effective approach to study, for the first time, the subsistence strategies, dietary behaviour and, for preliminary insights, mobility in Early medieval populations from the Italian Alps. The $\delta^{13} \mathrm{C}$ values showed, for all individuals, a terrestrial diet based on $\mathrm{C}_{3}$ plants with increasing proportions of $\mathrm{C}_{4}$ plants (e.g. millet, sorghum) at lower altitudes. The data clearly indicated that differences in the subsistence are more dependent on the environmental context, mainly on altitudes, rather than on cultural influences. When comparing the sites and valleys, with regard to their geographical location and altitudes ( $\mathrm{m}$ a.s.l.), enriched $\delta^{15} \mathrm{~N}$ values are noted at higher altitudes (Venosta valley), probably due to a diet richer in animal proteins and dairy products. Differences in $\delta^{15} \mathrm{~N}$ values might also be attributed to social status when considered in combination with recovered grave goods. The $\delta^{34} \mathrm{~S}$ data indicated higher variability in Adige valley compared to the other areas, suggesting greater mobility in Adige. In order to strengthen these findings, additional analyses are required. Future studies will include analyses of $\delta^{18} \mathrm{O}$ and partially ${ }^{87} \mathrm{Sr} /{ }^{86} \mathrm{Sr}$, and the isotopic data will be crosschecked with genetic data, which is within the framework of the ongoing interdisciplinary project (BioArchEM).

Acknowledgements The study was achieved with the permission of Catrin Marzoli (Ufficio 13.2 Beni archeologici, Autonomous Province of Bolzano, Italy), who approved the sampling of the human and animal bone remains as well as the consultation of unpublished data. We wish to acknowledge the help provided by Wilfried Rosendahl (REM, Germany) for support of radiocarbon dating, Andreas Rossmann (IsoLab, Germany) for stable isotope measurements, Katrin Renner (Eurac Research) for Fig. 1 editing and George Logan for language editing. We thank the anonymous reviewers for their precious advices and support.

Funding Information Open Access funding provided by Projekt DEAL.

Open Access This article is licensed under a Creative Commons Attribution 4.0 International License, which permits use, sharing, adaptation, distribution and reproduction in any medium or format, as 
long as you give appropriate credit to the original author(s) and the source, provide a link to the Creative Commons licence, and indicate if changes were made. The images or other third party material in this article are included in the article's Creative Commons licence, unless indicated otherwise in a credit line to the material. If material is not included in the article's Creative Commons licence and your intended use is not permitted by statutory regulation or exceeds the permitted use, you will need to obtain permission directly from the copyright holder. To view a copy of this licence, visit http://creativecommons.org/licenses/by/4.0/.

\section{References}

Acsádi G, Nemeskéri J (1970) History of human life span and mortality. Akadémiai Kiadó, Budapest

Albertoni G (2005) Romani e Germani come questione storiografica. In: Landi W (ed) Romani e Germani nel cuore delle Alpi tra V e VIII secolo. Athesia, Bolzano, pp 17-27

AlQathani SJ, Hector MP, Liversidge HM (2010) Brief communication: the London atlas of human tooth development and eruption. Am J Phys Anthropol 142:481-490. https://doi.org/10.1002/ajpa.21258

Ambrose SH (1990) Preparation and characterization of bone and tooth collagen for isotopic analysis. J Archaeol Sci 17:431-451. https:// doi.org/10.1016/0305-4403(90)90007-R

Ambrose SH (1993) Isotopic analysis of Paleodiets: methodological and interpretive considerations. In: Sandford MK (ed) Investigations of ancient human tissue: chemical analyses in anthropology. Food and nutrition in history and anthropology. Gordon and Breach Science Publisher Ltd, New York

Baker BJ, Dupras TL, Tocheri MW (2005) The osteology of infants and children. Texas A\&M UP, Texas

Baldoni M, Nardi A, Müldner G, Lelli R, Gnes M, Ferraresi F, Meloni V, Cerino P, Greco S, Manenti G, Angle M, Rickards O, MartínezLabarga C (2016) Archaeobiological reconstruction of the Italian medieval population of Colonna (8th-10th centuries CE). J Archaeol Sci Rep 10:483-494. https://doi.org/10.1016/j.jasrep. 2016.11.013

Banzi E (2005) Sistema daziario sulla rete viaria romana nel territorio altoatesino: vecchi e nuovi dati epigrafici. In: Ciurletti G, Pisu N (eds) I territori della Via Claudia Augusta. incontri di archeologia, Trento, pp 173-189

Barone R (1980) Anatomia comparata dei mammiferi domestici. In: Osteologia, vol I. Edagricole, Bologna

Bierbrauer V (1991) L'insediamento del Tardo Antico e alto Medioevo in Trentino-Alto Adige (V-VII secolo). Fondamentali caratteristiche archeologiche e notazioni per una carta sulla diffusione degli insediamenti. In: Menis GC (ed) Italia Longobarda. Marisilio editori, Venezia, pp 121-173

Bierbrauer V (2005) Romani e Germani fra V e VIII secolo dal punto di vista della ricerca archeologica. In: Landi W (ed) Romani e Germani nel cuore delle Alpi tra V e VIII secolo. Athesia, Bolzano, pp 213239

Bocherens H, Drucker DG, Billiou D, Geneste JM, van der Plicht J (2006) Bears and humans in Chauvet cave (Vallon-Pont-d'Arc, Ardèche, France): insights from stable isotopes and radiocarbon dating of bone collagen. J Hum Evol 50(3):370-376. https://doi. org/10.1016/j.jhevol.2005.12.002

Bollongino R, Nehlich O, Richards MP, Orschiedt J, Thomas MG, Sell C, Fajkosova Z, Powell A, BurgeR J (2013) 2000 years of parallel societies in stone age Central Europe. Science 342(6157):479481. https://doi.org/10.1126/science.1245049
Bonafini M, Pellegrini M, Ditchfield P, Pollard AM (2013) Investigation of the "canopy effect" in the isotope ecology of temperate woodlands. J Archaeol Sci 40(11):3926-3935

Brooks ST and Suchey JM (1990) Skeletal age determination based on the os pubis: a comparison of the Acsadi-Nemeskéri and SucheyBrooks methods. Human Evolution 5:227-238

Buikstra JE, Ubelaker DH (1994) Standards of data collection from human skeletal remains, 44. Arkansas Archeological Survey Research, Fayetteville

Carrer F, Colonese AC, Lucquin A, Petersen Guedes E, Thompson A, Walsh K, Reitmaier T, Craig OE (2016) Chemical analysis of pottery demonstrates prehistoric origin for high-altitude Alpine dairying. PLoS One 11:ARTN e0151442. https://doi.org/10.1371/journal. pone. 0151442

Castiglioni E, Tecchiati U (2005) Ricerche archeobotaniche nei livelli della tarda età del Rame di Velturno-Tanzgasse in val d'Isarco (BZ). Atti Acc Rov Agiati 255(5B):505-528

Cavada E (2004) Città territorio nell'alto medioevo alla luce delle fonti archeologiche. In: Castagnetti A, Varanin GM (eds) Storia del Trentino III, L'età medievale. Il Mulino, Bologna, pp 195-223

Cernusak LA, Tcherkez G, Keitel C, Cornwell WK et al (2009) Why are non-photosynthetic tissues generally $13 \mathrm{C}$ enriched compared to leaves in C3 plants? Review and synthesis of current hypotheses. Funct Plant Biol 36:199-213. https://doi.org/10.1071/Fp08216

Coia V, Boschi I, Trombetta F, Cavulli F, Montinaro F, Destro-Bisol G, Grimaldi S, Pedrotti A (2012) Evidence of high genetic variation among linguistically diverse populations on a micro-geographic scale: a case study of the Italian Alps. J Hum Genet 57(4):254 260. https://doi.org/10.1038/jhg.2012.14

Craig OE, Ross R, Andersen SH, Milner N, Bailey GN (2006) Focus: sulphur isotope variation in archaeological marine fauna from northern Europe. J Archaeol Sci 33:1642-1646

Craig OE, Biazzo M, O'Connell TC, Garnsey P, Martinez-Labarga C, Lelli R, Salvadei L, Tartaglia G, Nava A, Renó L, Fiammenghi A, Rickards O, Bondioli L (2009) Stable isotopic evidence for diet at the Imperial Roman coastal site of Velia (1st and 2nd centuries AD) in southern Italy. Am J Phys Anthropol 139:572-583. https://doi. org/10.1002/ajpa.21021

Czermak A, Ledderose A, Strott N, Meier T, Grupe G (2006) Social structures and social relations-an archaeological and anthropological examination of three early medieval separate burial sites in Bavaria. Anthropol Anz 64(3):297-310

Dal Ri L (2009) L'insediamento fortificato di Lamprecht nel comune di Appiano (Bolzano). Atti Acc. Rov. Agiati, a. 259, ser. VIII, vol IX, A, fasc. II, 1: 97-129

Dal Ri L, Rizzi G (1995) Il territorio atesino alla fine del VI e nel VII secolo d.C. In G.P. Brogiolo (Ed.). Città, castelli, campagne nei territori di frontiera (secoli VI-VII). $5^{\circ}$ seminario sul tardoantico e l'alto medioevo in Italia centro-settentrionale. Monte Barro, 9-10 giugno 1994 (Documenti di archeologia, 6), Mantova 1995, pp $87-114$

Dallago S (2016) Resti dell'abitato altomedievale di Villandro Plunacker (Bolzano): i reperti faunistici. Dissertation, University of Bologna, Italy

DeNiro MJ (1985) Postmortem preservation and alteration of invivo bone-collagen isotope ratios in relation to paleodietary reconstruction. Nature. 317:806-809. https://doi.org/10.1038/317806a0

DeNiro MJ, Epstein S (1978) Influence of diet on the distribution of carbon isotopes in animals. Geochim Cosmochim Acta 42:495506. https://doi.org/10.1016/0016-7037(78)90199-0

Drucker DG, Bridault A, Hobson KA, Szuma E, Bocherens H (2008) Can carbon-13 in large herbivores reflect the canopy effect in temperate and boreal ecosystems? Evidence from modern and ancient ungulates. Palaeogeogr Palaeoclimatol Palaeoecol 266:69-82

Drucker DG, Bridault A, Cupillard C, Hujic A, Bocherens H (2011) Evolution of habitat and environment of red deer (Cervus elaphus) 
during the late-glacial and early Holocene in eastern France (French Jura and the western Alps) using multi-isotope analysis $\left(\delta^{13} \mathrm{C}, \delta^{15} \mathrm{~N}\right.$, $\left.\delta^{18} \mathrm{O}, \delta^{34} \mathrm{~S}\right)$ of archaeological remains. Quat Int 245:268-278

Ehleringer JR, Sage RF, Flanagan LB, Pearcy RW (1991) Climate change and the evolution of $\mathrm{C} 4$ photosynthesis. Trends Ecol Evol 6:95-99. https://doi.org/10.1016/0169-5347(91)90183-X

Ehleringer JR, Bowling DR, Flanagan LB, Fessenden J, Helliker B, Martinelli A, Ometto P (2002) Stable isotopes and carbon cycle processes in forests and grasslands. Plant Biol 4:181-189

Fahy GE, Deter C, Pitfield R, Miszkiewicz JJ, Mahoney P (2017) Bone deep: variation in stable isotope ratios and histomorphometric measurements of bone remodelling within adult humans. J Archaeol Sci 87:10-16. https://doi.org/10.1016/j.jas.2017.09.009

Fazekas IGY, Kósa F (1978) Forensic fetal osteology. Akademiai Kaido, Budapest

Ferembach D, Schwidetzky I, Stloukal M (1979) Empfehlungen für die Alters- und Geschlechtsdiagnose am Skelett. Homo 30:1-32

Ferrio JP, Voltas J, Araus JL (2003) Use of carbon isotope composition in monitoring environmental changes. Manag Environ Qual 14:82-98. https://doi.org/10.1108/14777830310460405

Festi D, Tecchiati U, Steiner H, Oeggl K (2011) The copper age settlement of Latsch: archaeobotanical and archaeozoological results from a valley settlement coeval to the alpine iceman and located in his valley of origin. Veget Hist Archaeobot 20(5):367-379. https:// doi.org/10.1007/s00334-011-0308-0

Flandrin JL, Montanari M (2007) Storia dell'alimentazione. Editori Laterza, Roma

Fry B (2006) Stable isotope ecology. Springer-Verlag, New York

Fuller BT, De Cupere B, Marinova E, Van Neer W, Waelkens M, Richards MP (2012) Isotopic reconstruction of human diet and animal husbandry practices during the classical-Hellenistic, imperial, and byzantine periods at Sagalassos, Turkey. Am J Phys Anthropol 149:57-171

Gasparri S, La Rocca C (2013) Tempi barbarici. In: L'Europa occidentale tra antichità e medioevo 300-900. Carrocci Editore, Roma

Giostra C, Lusuardi Siena S (2004) Le popolazioni germaniche in Italia: le testimonianze di epoca altomedievale a sud dello spartiacque alpino. In: Gleirscher P, Marzatico F (eds) Guerrieri Principi ed Eroi fra il Danubio e il Po dalla preistoria all'alto Medioevo. Museo Castello Buonconsiglio, Trento, pp 513-527

Guiry EJ (2012) Dogs as analogs in stable isotope-based human palaeodietary reconstruction. J Archaeol Method Theory 19(3): 351-376. https://doi.org/10.1007/s10816-011-9118-z

Haas-Gebhard B (2004) A Nord delle Alpi: Franchi, Alamanni e Baiuvari. In: Gleirscher P, Marzatico F (eds) Guerrieri Principi ed Eroi fra il Danubio e il Po dalla preistoria all'alto Medioevo. Museo Castello Buonconsiglio, Trento, pp 529-540

Hakenbeck S, McManus E, Geisler H, Grupe G, O'Connell T (2010) Diet and mobility in early medieval Bavaria: a study of carbon and nitrogen stable isotopes. Am J Phys Anthropol 143(2):235-249. https:// doi.org/10.1002/ajpa.21309

Hakenbeck SE, Evans J, Chapman H, Fóthi E (2017) Practicing pastoralism in an agricultural environment: an isotopic analysis of the impact of the Hunnic incursions on Pannonian populations. PLoS One 12(3):e0173079. https://doi.org/10.1371/journal.pone.0173079

Halffman CM, Velemínský P (2015) Stable isotope evidence for diet in early medieval great Moravia (Czech Republic). J Archaeol Sci 2:18. https://doi.org/10.1016/j.jasrep.2014.12.006

Hedges REM, Reynard LM (2007) Nitrogen isotopes and the trophic level of humans in archaeology. J Archaeol Sci 34:1240-1125

Heitmeier I (2005) Das Inntal. Siedlungs-und Raumentwicklung eines Alpentales im Scnittpunkt der politischen Interessen von der römischen Okkupation bis in die Zeit Karls des Großen. Studien zur Frühgeschichte des historischen Tiroler Raumes I. (SchlernSchriften). Wagner Innsbruck, Innsbruck
Hemer KA, Evans JA, Chenery CA, Lamb AL (2013) Evidence of early medieval trade and migration between Wales and the Mediterranean Sea region. J Archaeol Sci 40:2352-2359

Hoefs J (2009) Stable isotope geochemistry. Springer-Verlag, Berlin, Heidelberg

Hoogewerff J, Papesch W (2001) The last domicile of the iceman from Hauslabjoch: a geochemical approach using $\mathrm{Sr}, \mathrm{C}$ and $\mathrm{O}$ isotopes and Trace element signatures. J Archaeol Sci 28:983-989. https:// doi.org/10.1006/jasc.2001.0659

Hughes MK, Diaz HF (1994) The medieval warm period. Springer, Dordrecht. https://doi.org/10.1007/978-94-011-1186-7

Iacumin P, Galli E, Cavalli F, Cecere L (2014) C4-consumers in southern Europe: the case of Friuli V.G. (NE-Italy) during early and central Middle Ages. Am J Phys Anthropol 154:561-574. https://doi.org/ 10.1002/ajpa.22553

Katzenberg MA (2008) Stable isotope analysis: a tool for studying past diet, demography, and life history. In: Katzenberg MA, Saunders SR (eds) Biological anthropology of the human skeleton. Wiley-Liss, Hoboken, pp 413-441

Kaufmann G, Demetz S (2004) Dal riparo alla città. Cenni sulla preistoria e sulla prima storia di Bressanone. In: Fuchs B, Heiss H, Milesi C, Pfeifer G (eds) Bressanone. I. La storia. Athesia, Lana, pp 29-88

Knipper C, Peters D, Meyer C, Maurer AF, Muhl A, Schöne BR, Alt KW (2012) Dietary reconstruction in migration period Central Germany: a carbon and nitrogen isotope study. Archaeol Anthropol Sci 5(1): 17-35. https://doi.org/10.1007/s12520-012-0106-3

Kustatscher E, Romeo C (2010) Passaggi e prospettive, lineamenti di storia locale 1. In: L'area tirolese dalla preistoria al tardo Medioevo. Athesia, Bolzano

Laffranchi Z, Delgado-Huertas A, Jiménez-Brobeil SA, Granado-Torres A, Riquelme-Cantal JA (2016) Stable C \& N isotopes in 2100 yearB.P. human bone collagen indicate rare dietary dominance of $\mathrm{C} 4$ plants in NE-Italy. Sci Rep 6:38817. https://doi.org/10.1038/ srep38817

Lanzinger M, Marzatico F, Pedrotti A (2000) Storia del Trentino I. In: La preistoria e la protostoria. Il Mulino, Bologna

Le Huray JD, Schutkowski H (2005) Diet and social status during the La Tène period in Bohemia: carbon and nitrogen stable isotope analysis of bone collagen from Kutná Hora-Karlov and Radovesice. J Anthropol Archaeol 24:135-147. https://doi.org/10.1016/j.jaa. 2004.09.002

Lee-Thorp JA (2008) On isotopes and old bones. Archaeometry 50:925950. https://doi.org/10.1111/j.1475-4754.2008.00441.x

Lee-Thorp JA, Sealy JC, Van der Merwe NJ (1989) Stable carbon isotope ratio differences between bone collagen and bone apatite, and their relationship to diet. J Archaeol Sci 16:585-599

Longin R (1971) New method of collagen extraction for radiocarbon dating. Nature 230:241-242. https://doi.org/10.1038/230241a0

Lösch S (2009) Paläopathologisch-anthropologische und molekulare Untersuchungen an mittelalterlichen und frühneuzeitlichen Bevölkerungsgruppen Ernährung und Gesundheitszustand südund nordbayerischer Bevölkerungsstichproben. Dissertation, Universität München, Germany. Available at https://edoc.ub.unimuenchen.de/9899/

Lösch S, Gruppe G, Peters J (2006) Stable isotopes and dietary adaptations in humans and animals at pre-pottery Neolithic Nevalli Cori, Southeast Anatolia. Am J Phys Anthropol 131:181-193. https://doi. org/10.1002/ajpa.20395

Lösch S, Moghaddam N, Grossschmidt K, Risser DU, Kanz F (2014) Stable isotope and Trace element studies on gladiators and contemporary romans from Ephesus (Turkey, 2nd and 3rd Ct. AD) - implications for differences in diet. PLoS One 9(10). https://doi.org/10. 1371/journal.pone.0110489

Lunz R (1974) Studien zur End-Bronzezeit und älteren Eisenzeit im Südalpenraum. Sansoni, Firenze 
Macko SA, Lubec G, Teschler-Nicola M, Andrusevich V, Engel MH (1999) The ice man's diet as reflected by the stable nitrogen and carbon isotopic composition of his hair. FASEB J 13:559-562

Mann ME, Zhang Z, Rutherford S, Bradley RS, Hughes MK, Shindell D, Ammann C, Faluvegi G, Ni F (2009) Global signatures and dynamical origins of the little ice age and medieval climate anomaly. Science 326(5957):1256-1260. https://doi.org/10.1126/science. 1177303

Maresh MM (1970) Measurements from roentgenograms, heart size, long bone lengths, bone, muscle and fat widths, skeletal maturation. In: McCammon RW (ed) Human growth and development. Charles C. Thomas, Springfield, pp 155-200

Marzoli C (2002) Die Kirchengrabung von Tirol. In: Dal Ri L, Di Stefano $\mathrm{S}$ (eds) Archeologia romana in Alto Adige, Beni Culturali in Alto Adige, Studi e ricerche 1. Folio Editore, Bolzano, pp 1053-1069

Marzoli C, Bombonato G, Rizzi G (2009) Nuovi dati archeologici sull'insediamento tardo antico-altomedievale della Valle dell'Adige tra la Merano basin e Salorno. Atti Acc. Rov. Agiati, 259 ser. VIII, vol IX, A, fasc. II, 1: 145-183

McGlynn G (2007) Using ${ }^{13} \mathrm{C}$-, ${ }^{15} \mathrm{~N}$ - and ${ }^{18} \mathrm{O}$ stable isotope analysis of human bone tissue to identify transhumance, high altitude habitation and reconstruct palaeodiet for the early medieval Alpine population at Volders, Austria. Dissertation, Universität München, Germany. Available at http://edoc.ub.uni-muenchen.de/7327/1/McGlynn George.pdf.pdf

Meier-Augenstein W (2010) Stable isotope forensics. An introduction to the forensic application of stable isotope analysis. Wiley, Chichester

Meindl RS, Lovejoy CO (1985) Ectocranial suture closure: a revised method of age determination of skeletal age at death based on the lateral-anterior sutures. Am J Phys Anthropol 68:57-66

Minagawa M, Wada E (1984) Stepwise enrichment of ${ }^{15} \mathrm{~N}$ along food chains. Geochim Cosmochim Acta 48:1135-1140. https://doi.org/ 10.1016/0016-7037(84)90204-7

Moghaddam N, Müller F, Hafner A, Lösch S (2016) Social stratigraphy in late Iron age Switzerland: stable carbon, nitrogen and sulphur isotope analysis of human remains from Münsingen. Archaeol Anthropol Sci 8:149-160. https://doi.org/10.1007/s12520-0140221-4

Moghaddam N, Müller F, Lösch S (2018) A bioarchaeological approach to the Iron age in Switzerland: stable isotope analyses $\left(\delta^{13} \mathrm{C}, \delta^{15} \mathrm{~N}\right.$, $\left.\delta^{34} \mathrm{~S}\right)$ of human remains. Archaeol Anthropol Sci 10(5):1067-1085. https://doi.org/10.1007/s12520-016-0441-x

Montanari M, Baruzzi M (1981) Porci e porcari nel Medioevo: paesaggio, economia, alimentazione. CLUEB, Bologna

Murail P, Bruzek J, Houët F, Cunha E (2005) DSP: a tool for probabilistic sex diagnosis using worldwide variability in hip-bone measurements. Bul Mém Soc Anthrop Paris 17(3-4):167-176

Nehlich O (2015) The application of sulphur isotope analyses in archaeological research: a review. Earth Sci Rev 142:1-17. https://doi.org/ 10.1016/j.earscirev.2014.12.002

Nehlich O, Richards MP (2009) Establishing collagen quality criteria for sulphur isotope analysis of archaeological bone collagen. Archaeol Anthropol Sci 1:59-75

Nehlich O, Fuller BT, Jay M, Mora A, Nicholson RA, Smith CI, Richards MP (2011) Applications of sulphur isotope ratios to examine weaning patterns and freshwater fish consumption in Roman Oxfordshire, UK. Geochim Cosmochim Acta 75:4963-4977. https://doi.org/10.1016/j.gca.2011.06.009

Nehlich O, Fuller BT, Márquez-Grant N, Richards MP (2012) Investigation of diachronic dietary patterns on the islands of Ibiza and Formentera, Spain: evidence from sulfur stable isotope ratio analysis. Am J Phys Anthropol 149:115-124. https://doi.org/10. 1002/ajpa.22104

Nehlich O, Oelze V, Jay M, Conrad M, Stäuble H, Teegen W, Richards MP (2014) Sulphur isotope ratios of multi-period archaeological skeletal remains from Central Germany: a dietary and mobility study. Anthropologie (BRNO) LII:15-33

Nelson DE, Angerbjörn A, Lidén K, Turk I (1998) Stable isotopes and the metabolism of the European cave bear. Oecologia 116:177-181. https://doi.org/10.1007/s004420050577

Nisbet R (2008) Wood use and agriculture at Villandro/Villanders (Bolzano/Bozen, alto Adige/South Tyrol): the charred remains from Mesolithic to middle ages. Atti Soc Preist Protost Friuli- V.G., Trieste, pp 75-131

Oelze V, Koch JK, Kupke K, Nehlich O, Zäuner S, Wahl J, Weise SM, Rieckhoff S, Richards MP (2012) Multi-isotopic analysis reveals individual mobility and diet at the early Iron age monumental tumulus of Magdalenenberg, Germany. Am J Phys Anthropol 148:406421. https://doi.org/10.1002/ajpa.22063

Öggl KD (1993) Die Planzenreste aus der Ausgrabung bei der Kirche Sankt Laurentius, in Der Vinschgau und seine Nachbarräume. Vorträge des landeskundlichen Symposiums veranstaltet vom Südtiroler Kulturinstitut in Verbindung mit dem Bildunghaus Schloss Goldrain: Schloss Goldrain 27. Bolzen pp 65-69

Olsen KC, White CD, Longstaffe FJ, von Heyking K, McGlynn G, Grupe G, Rühli FJ (2014) Intraskeletal isotopic compositions ( $\delta(13) \mathrm{C}$, $\delta(15) \mathrm{N})$ of bone collagen: nonpathological and pathological variation. Am J Phys Anthropol 153(4):598-604. https://doi.org/10. 1002/ajpa.22459

Ortolani F, Pagliuca S (2007) Evidenze geologiche di variazioni climatico-ambientalistoriche nell'Area Mediterranea. In: Wezel F (ed) Variabilità naturale del clima nell'Olocene ed in tempi storici: un approccio geologico. Società Geologica Italiana, Roma, pp 1317

Polet C, Katzenberg MA (2003) Reconstruction of the diet in a mediaeval monastic community from the coast of Belgium. J Archaeol Sci 30: 525-533. https://doi.org/10.1016/S0305-4403(02)00183-8

Prevedorou E, Díaz-Zorita Bonilla M, Romero A, Buikstra J, Paz de Miguel Ibáñez M, Knudson KJ (2010) Residential mobility and dental decoration in early medieval Spain: results from the eighth century site of plaza del Castillo, Pamplona. Dent Anthropol 23(2): $42-52$

Privat K, O'Connell TC, Hedges REM (2007) The distinction between freshwater and terrestrial-based diets: methodological concerns and archaeological applications of sulphur stable isotope analysis. J Archaeol Sci 34:1197-1204. https://doi.org/10.1016/j.jas.2006.10. 008

Reitsema LJ, Vercellotti G (2012) Stable isotope evidence for sex- and status-based variations in diet and life history at medieval Trino Vercellese, Italy. Am J Phys Anthropol 148:589-600. https://doi. org/10.1002/ajpa.22085

Reitsema LJ, Crews DE, Polcyn M (2010) Preliminary evidence for medieval polish diet from carbon and nitrogen. J Archaeol Sci 37: 1413-1423. https://doi.org/10.1016/j.jas.2010.01.001

Reuß OM (2016) St. Stephan ob Burgeis im Kontext des mittelalterlichen Kirchenbaus im Alpenraum. In: Auswertung der Grabungen und historische Kontextualisierung. Verlag Dr.Kovač, Hamburg

Richards MP, Hedges REM, Molleson TI, Vogel JC (1998) Stable isotope analysis reveals variations in human diet at the Poundbury camp cemetery site. J Archaeol Sci 25:1247-1252. https://doi.org/10. 1006/jasc. 1998.0307

Richards MP, Fuller BT, Hedges REM (2001) Sulphur isotopic variation in ancient bone collagen from Europe: implications for human paleodiet, residence mobility and modern pollutant studies. Earth Planet Sci Lett 191:185-190. https://doi.org/10.1016/S0012821X(01)00427-7

Richards MP, Pearson JA, Molleson TI, Russell N, Martin L (2003) Stable isotope evidence of diet at Neolithic Çatalhöyük, Turkey. J Archaeol Sci 30(1):67-76. https://doi.org/10.1006/jasc.2001.0825

Riedel A (1979) Die Fauna einer frühmittelalterlichen Siedlung in Stufels bei Brixen. Der Schlern 53(7):3-23 
Sardagna M, Tecchiati U (2010) La fauna dell'abitato del primo Medioevo di San Genesio, Loc. SS. Cosma e Damiano (Bolzano). Scavi 2005, in Atti del $5^{\circ}$ Convegno Nazionale di Archeozoologia, Rovereto

Schaefer M, Black S, Scheuer L (2009) Developmental juvenile osteology: A Laboratory and Field Manual. Elsevier Academic Press, London

Scheeres M, Knipper C, Hauschild M, Schönfelder M, Siebel W, Vitali D et al (2013) Evidence for "Celtic migrations"? Strontium isotope analysis at the early La Tène (LT B) cemeteries of Nebringen (Germany) and Monte Bibele (Italy). J Archaeol Sci 40(10):3614 3625

Schmid E (1972) Atlas of animal bones: for prehistorians. Archaeologists and Quaternary Geologists. Elsevier Pub. Co, New York

Schoeniger MJ, DeNiro MJ (1984) Nitrogen and carbon isotopic composition of bone collagen from marine and terrestrial animals. Geochim Cosmochim Acta 43:625-638. https://doi.org/10.1016/ 0016-7037(84)90091-7

Schutkowski H, Herrmann B (1999) Diet, status and decomposition at Weingarten: trace element and isotope analyses on early mediaeval skeletal material. J Archaeol Sci 26:675-685. https://doi.org/10. 1006/jasc.1998.0384

Suchey JM, Katz D (1986) Skeletal age standards derived from an extensive multiracial sample of modern Americans. Paper presented at the 55th annual meeting of the American Association of Physical Anthropologists, Albuquerque, NM

Tafuri MA, Graig OE, Canci A (2009) Stable isotope evidence for the consumption of millet and other plants in bronze age Italy. Am J Phys Anthropol 139:146-153. https://doi.org/10.1002/ajpa.20955

Tafuri MA, Goude G, Manzi G (2018) Isotopic evidence of diet variation at the transition between classical and post-classical times in Central Italy. J Archaeol Sci Rep 21:496-503. https://doi.org/10.1016/j. jasrep.2018.08.034

Tecchiati U (2009) I resti faunistici dell'abitato tardoantico e del primo Medioevo di Lamprecht presso Appiano. Atti Acc. Rov. Agiati, 259, ser. VIII, vol IX, A, fasc. II, 1: 131-143

Tecchiati U, Zanforlin L (2010) Topografia archeologica della Bassa Atesina (Prov. di Bolzano). In: Dal Ri L, Gamper P, Steiner H (eds). Höhensiedlungen der Bronze- und Eisenzeit. Kontrolle der Verbindungswege über die Alpen - Abitati d'altura dell'età del Bronzo e del Ferro. Controllo delle vie di comunicazione attraverso le Alpi. Forschungen zur Denkmalpflege in Südtirol, VI, Beni culturali in Alto Adige. Studi e ricerche, pp 597-646

Tinner W, Lotter AF, Ammann B (2003) Climatic change and contemporaneous land-use phases north and south of the Alps $2300 \mathrm{BC}$ to 800 AD. Quat Sci Rev 22:1447-1460. https://doi.org/10.1016/S02773791(03)00083-0

Ubelaker DH (1978) Human skeletal remains: excavation, analysis and interpretation. Taraxacum, Washington

Van der Merwe NJ, Medina E (1991) The canopy effect, carbon isotope ratios and foodwebs in Amazonia. J Archaeol Sci 18:249-259. https://doi.org/10.1016/0305-4403(91)90064-V

Van Klinken GJ (1999) Bone collagen quality indicators for Palaeodietary and radiocarbon measurements. J Archaeol Sci 26(6):687-695. https://doi.org/10.1006/jasc.1998.0385

Van Klinken GJ, Richards MP, Hedges REM (2000) An overview of causes for stable isotopic variations in past European human populations: environmental, Ecophysiological, and cultural effects. In: Ambrose SH, Katzenberg MA (eds) Biogeochemical approaches to Paleodietary analysis. Kluwer Academic/Plenum Publisher, New York, pp 39-63

Varalli A, Moggi-Cecchi J, Dori I, Boccone S, Bortoluzzi S, Salzani P, Tafuri MA (2016) Dietary continuity vs. discontinuity in bronze age Italy. The isotopic evidence from Arano di Cellore (Illasi, Verona, Italy). J Archaeol Sci Rep 7:104-113. https://doi.org/10.1016/j. jasrep.2016.03.047

Vika E (2009) Strangers in the grave? Investigating local provenance in a Greek bronze age mass burial using delta $\mathrm{S}_{34}$ analysis. J Archaeol Sci 36:2024-2028. https://doi.org/10.1016/j.jas.2009.05.022

Winckler C (2012) Die Alpen im Frühmittelalter, Die Geschichte eines Raumes in den Jahren 500 bis 800 . Böhlau, Wien

Publisher's note Springer Nature remains neutral with regard to jurisdictional claims in published maps and institutional affiliations. 